Article

\title{
A Step towards a Sustainable Tourism in Apennine Mountain Areas: A Proposal of Geoitinerary across the Matese Mountains (Central-Southern Italy)
}

\author{
Francesca Filocamo ${ }^{1, *(D)}$, Carmen Maria Rosskopf ${ }^{1}\left(\mathbb{D}\right.$, Vincenzo Amato ${ }^{1}$ and Massimo Cesarano $^{2}$ \\ 1 Department of Biosciences and Territory, University of Molise, Contrada Fonte Lappone, \\ 86090 Pesche, IS, Italy; rosskopf@unimol.it (C.M.R.); vincenzo.amato@unimol.it (V.A.) \\ 2 Institute of Environmental Geology and Geoengineering (IGAG), National Research Council (CNR), \\ Via Salaria km 29,300, 00015 Montelibretti, RM, Italy; massimo.cesarano@igag.cnr.it \\ * Correspondence: francesca.filocamo@gmail.com; Tel.: +39-0874-404168
}

Citation: Filocamo, F.; Rosskopf,

C.M.; Amato, V.; Cesarano, M. A Step

towards a Sustainable Tourism in

Apennine Mountain Areas: A

Proposal of Geoitinerary across the

Matese Mountains (Central-Southern

Italy). Geosciences 2022, 12, 100.

https://doi.org/10.3390/

geosciences 12020100

Academic Editors: Hara Drinia,

Panagiotis Voudouris and Assimina

Antonarakou

Received: 17 January 2022

Accepted: 17 February 2022

Published: 21 February 2022

Publisher's Note: MDPI stays neutral with regard to jurisdictional claims in published maps and institutional affiliations.

Copyright: (c) 2022 by the authors. Licensee MDPI, Basel, Switzerland. This article is an open access article distributed under the terms and conditions of the Creative Commons Attribution (CC BY) license (https:// creativecommons.org/licenses/by/ $4.0 /)$.

\begin{abstract}
The Apennine mountain areas suffer progressive abandonment and marginality, although being characterized by an extraordinary richness in natural and cultural resources, and landscapes of great beauty. Therefore, their natural heritage, and especially their geoheritage, tranformed into geotourism initiatives, can represent an essential resource to support local economy andsustainable development. The present study illustrates the case of Matese Mountains (Southern Apennines), particularly rich in protected areas, including the Matese National Park currently taking off, which is characterized by a rich geoheritage, based on 59 geosites. Among these geosites, examining the specially built geosite GIS database, 16 geosites were selected to construct a geoitinerary crossing the Matese Mountains. The geoitinerary was delineated to optimally represent the major geomorphological and geological (especially geohistorical) features of the Matese area. The selected geosites were associated to a new procedure to assess their Scientific Value (SV) and Potential Tourism Use (PTU), and to confirm their suitability for the purpose. To illustrate the geoitinerary, a geoitinerary map, and illustration material such as descriptive cards were produced. As an overall result, the proposed geoitinerary represents a valuable contribution for the geotourism promotion of the Matese Mountains on which to base future studies and initiatives in this perspective.
\end{abstract}

Keywords: inner areas; natural resources; geosites; geoheritage; geotourism; Matese National Park; Southern Apennines

\section{Introduction}

The Mediterranean mountain ranges (Alps, Apennines, Pyrenees, Atlas, etc.) are areas of priority interest due to their natural resources, especially for their richness in fauna and flora and relatively high biodiversity. Likewise, these mountainous areas are also of high geological interest as they testify important steps of the geological history of the Earth and host highly diversified landscapes, which result from the prolonged interplay of endogenic and exogenic processes under variable climate conditions. This makes the need for natural resource protection a priority for Mediterranean mountain areas, implicating a substantial maintenance of their environmental features and values.

At the same time, Mediterranean mountain areas are largely part of the so-called inner areas, i.e., rural areas that experience marginalization due to their geographical and socio-economic conditions ([1,2] and references therein), and are significantly affected by demographic decline and population ageing, as well as landscape degradation caused primarily by agricultural abandonment ([3] and references therein).

The set of these characteristics, together with the significant geographical space that mountain areas occupy, make them become priority objects of sustainable development policies (e.g., [4]). 
In Europe, among the several initiatives aimed at reversing depopulation and marginalization of peripheral areas, one worthy of mentioning is the National Strategy for Inner Areas (NSIA), launched in 2012 by the Italian Government, that counts among its main themes the defense and usage of cultural heritage [5]. This theme implicates a contrast between interventions aimed at nature protection, especially the institution and management of protected areas (from special protection areas up to national parks), widespread at the European scale, and others that focus on the exploitation of the cultural heritage and the socio-economic development of the territory.

Obviously, the Mediterranean mountain areas, thanks to their landscapes of exceptional aesthetic quality [6] and richness in natural and cultural resources, are important potential destinations of tourism activities that, however, have to "unite under the same umbrella" the need of environment preservation with the desired socio-economic development. It is also for this reason that concepts such as mountain tourism [6,7], sustainable tourism, eco-tourism and slow travel ([8,9] and references therein), as well as geotourism [9-12], are progressively developing and gaining increasing importance.

In our specific case, research focuses on geotourism, which is intended as a geologybased tourism [12] and, according to [9], as tourism which focuses on an area's geology and landscape as the basis of fostering sustainable tourism development. Geotourism is one of the newest concepts in tourism studies today. It has grown rapidly over the past few decades and the potential for geotourism development is largely going to be explored in European and Mediterranean countries (e.g., [13-16] and references therein). Particularly, geotourism is among the novel strategies used for socio-economic development in rural areas $[17,18]$, and has been demonstrated to have positive economic effects in several contexts and especially in Geopark areas, both at the European and global scale (e.g., [17,19-21] and references therein).

Geotourism activities essentially concern the knowledge and exploitation of the geological heritage of a territory. They can represent a valid alternative or integration to other more or less traditional tourism activities in mountain areas, especially for summer seasons, even more as being able to respond to the need to promote scientific research and environmental education. Numerous are the activities that can be realized in several contexts, to promote geological heritage and related geotourism purposes, e.g., [22-25]. Among these, geological itineraries are a powerful tool for the dissemination of geosciences and geotourism development [26-29]. In fact, a consistent part of the recent and rich literature on geotourism concerns the proposal, design and/or illustration of geoitineraries [30-40], especially in Parks and/or Geoparks (i.e., [41-49]).

Among the major mountain areas in Italy, the Matese Mountains (Figure 1) well meet several of the previously mentioned characteristics of Mediterranean mountain areas. However, as regards the current exploitation of its geological heritage, there are only a few initiatives aimed at the promotion of geotourism. Among them, worth mentioning are the geoitineraries proposed respectively for the Molise sector [50,51] and for the Campanian sector [52,53], the two sectors into which the Matese mountains are subdivided from the administrative point of view (see below).

To contribute to the enhancement of the geological heritage of the Matese Mountains, in order to take a step towards the development of sustainable tourism, we have developed a proposal for a geoitinerary that crosses the entire Matese Mountains.

The geosite selection and the definition of the itinerary were based on several criteria (see below), to respond to the following essential requirements: (i) to best enhance the overall geological heritage of the Matese area, (ii) to illustrate in the most complete and optimal way the main steps of its geological history and landscape evolution, and (iii) to overcome the administrative and physiographic boundaries between the Campanian and Molise sectors of the Matese area. 


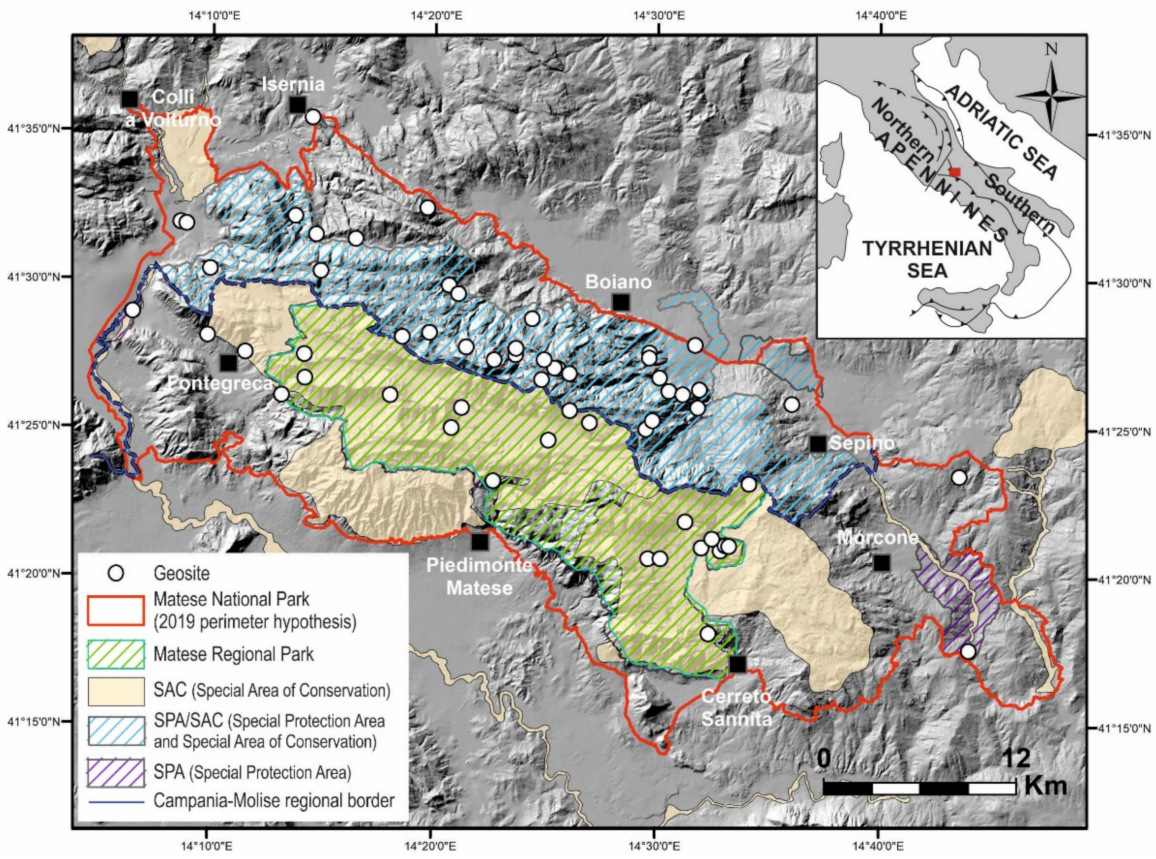

Figure 1. The Matese Mountains. Major protected natural areas and the 2019 perimeter hypothesis of the future Matese National Park are shown.

\section{Study Area}

The Matese Mountains formed during the Apenninic orogenesis that started following the closure of the Tethys Sea, with the deformation, piling up and uplift of thousands of meters thick marine sedimentary successions that had mainly deposited in carbonate platform environments (e.g., [54]). This group of mountains is placed in the junction zone between the southern and the northern Apennine arcs (Figure 1), and has been object of numerous geological studies since the end of the 1700 [55]. The major geological topics dealt with in the literature, for this sector, concern the tectonic evolution and deformation styles that have characterized it (e.g., [56-59]), the stratigraphy of the Mesozoic-Cenozoic successions (e.g., [60] and references therein), as well as the related palaeogeographic, paleoenvironmental and paleontological aspects (e.g., [54] and references therein, [61,62]).

The Matese Mountains are prevailingly composed of shallow water limestones and dolostones of Triassic to Miocene age (Figure 2), referring to carbonate platform domains. Towards their southeast, a major N-S tectonic feature puts these successions in contact with a tectonic unit composed of varicoloured clays, limestones, marls and arenites belonging to the basinal Sannio Units, and of sandstones and conglomerates of the San Bartolomeo Flysch (Figure 2). Furthermore, sandstones, clays and conglomerates belonging to the Miocene Molise Flysch are locally present both along the borders of the carbonate massif and inside it, within some major tectonic depressions (Figure 2). Rocks of Pliocene age are instead totally lacking in the Matese area. Finally, Quaternary deposits, which are mainly of alluvial and volcanic origin (Figure 2), crop out widespread in the basins and river plains surrounding the Matese Mountains, as well as in most of its major intramountainous tectonic depressions.

From the Late Pliocene onwards, the activity of extensional, mainly NW-SE to W-E and NE-SW oriented faults, caused the progressive tectonic fragmentation of the Matese Mountains. Clear evidence of this is found in the major intramountainous depressions (such as those that host the Matese and Gallo lakes) and the staircases of normal faults, responsible for the progressive relative tectonic lowering, especially towards NE and SW [63-67], of the external sectors of the massif, as well as of the basins around it (Figures 2 and 3). 


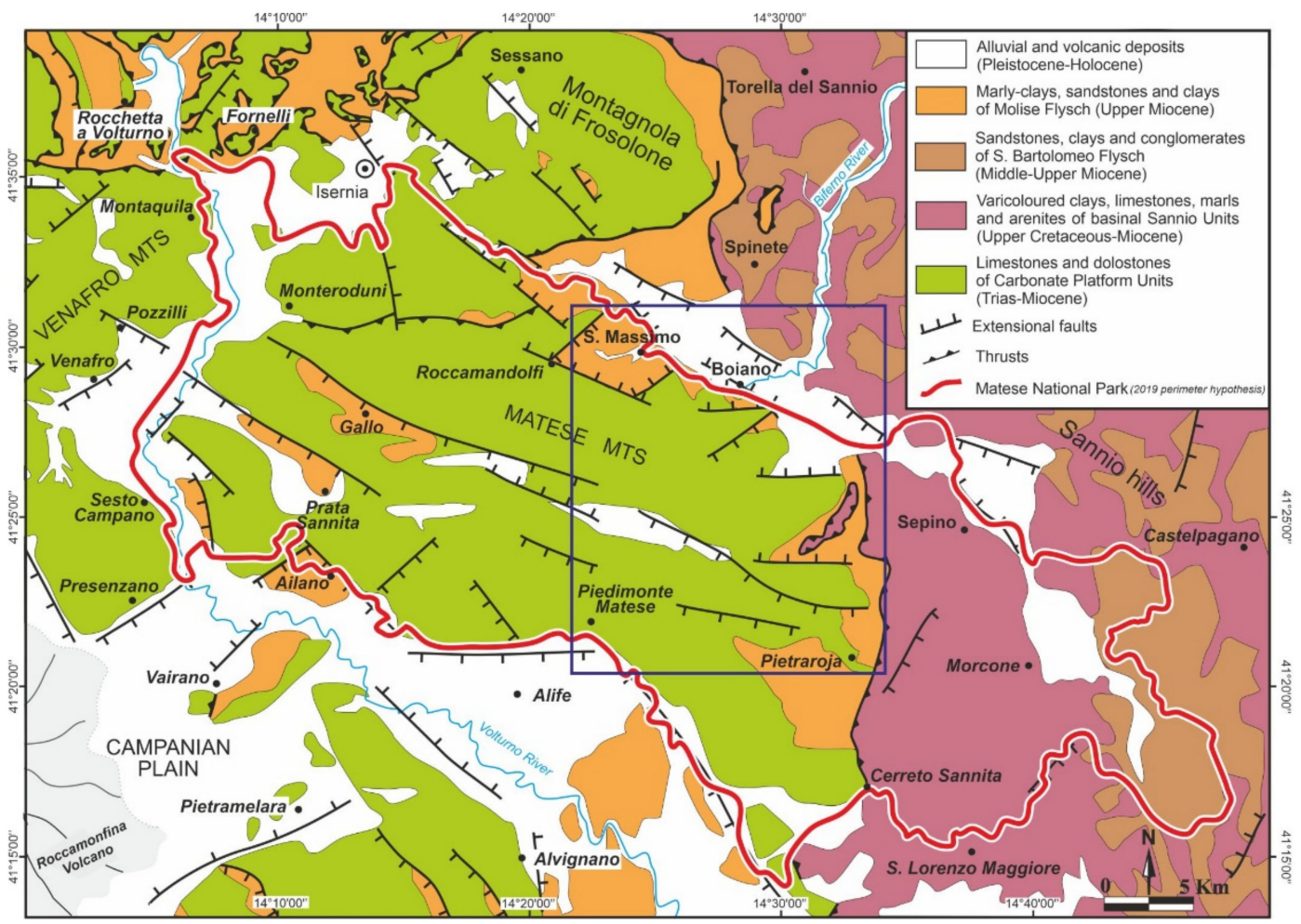

Figure 2. Schematic geologic map of the Matese area and surroundings. The blue frame limits the area selected for the geoitinerary proposal.

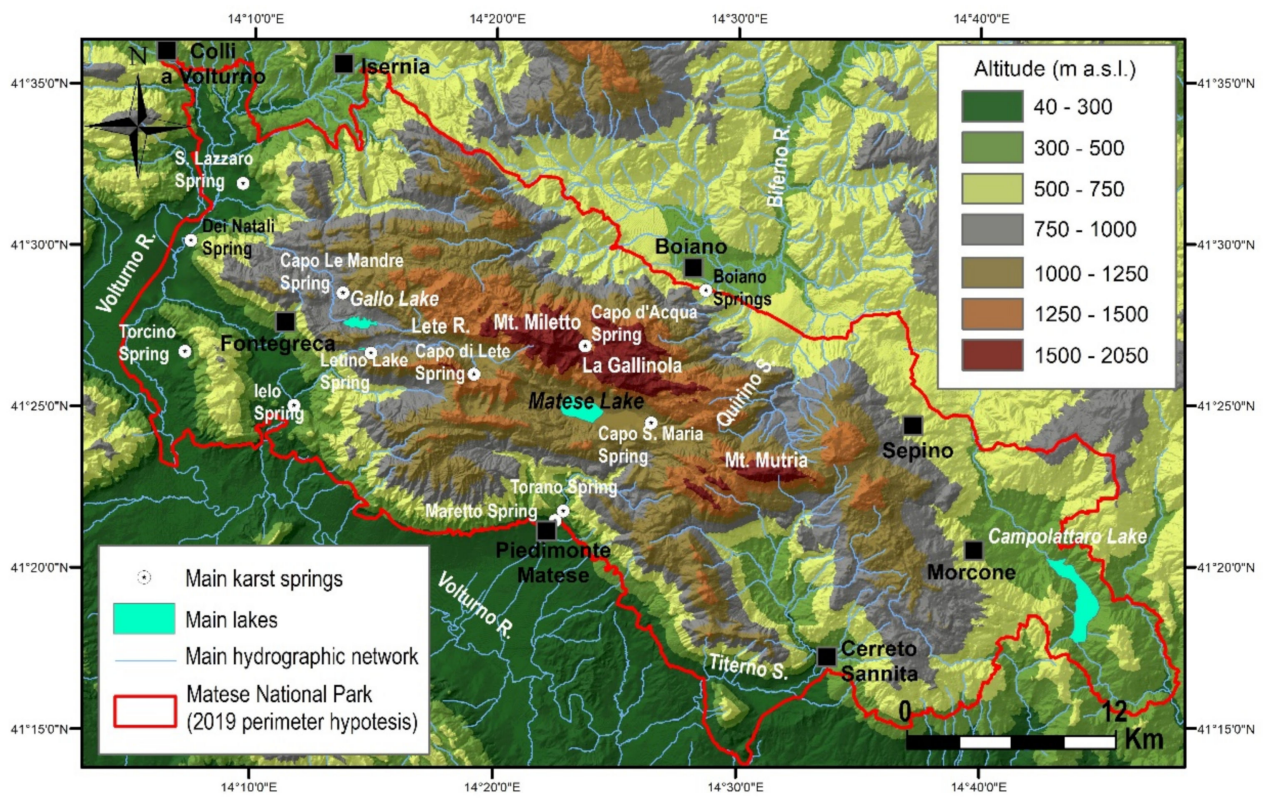

Figure 3. Main altitudinal-hydrographic features of the study area.

Extensional tectonics has significantly controlled the orographic-hydrographic setting of the Matese Mountains. The latter, in fact, are characterized by a central wide mountain to high mountain plateau-like sector with altitudes of above $1000 \mathrm{~m}$ and up to $2050 \mathrm{~m}$ a.s.l. (Figure 3), which is limited towards the surrounding hills and plains by huge, up to several hundreds of meters high carbonate fault slopes and structural-controlled slopes (Figures 2 and 3). The surface water drainage within the massif appears deeply controlled by fault and thrust alignments. Furthermore, major karst springs (see for instance the Boiano and the Torano-Maretto springs that emerge respectively along the central northern 
and southern edges of the Massif, Figure 3), are located along the contact between the carbonate karstified system and the surrounding low-permeability to impermeable rocks.

From a morphodynamic point of view, the Matese Massif typically represents the Mediterranean and, especially, the Apennine mountain landscape [68], whose landforms have evolved under the long lasting influence and interplay of tectonics and climate. In particular, with a maximum height of $2050 \mathrm{~m}$ (Mount Miletto), the Matese massif is one of the few mountainous areas in central-southern Italy that hosts significant evidence of Middle to Late Pleistocene glaciations, particularly relicts of glacial landforms (cirques and troughs) and remnants of moraines [69,70]. Apart from these important paleoclimatic relicts, the Matese Mountains are particularly rich in karst landforms due to their carbonate nature, and are furthermore characterized above all by periglacial, tectonic-structural and fluvial landforms $[68,70]$.

From an administrative and geographical point of view, the Matese area is divided into a southern and northern sector, falling respectively in the Campanian and Molise region (Figure 1). This circumstance has surely contributed to a certain fragmentation of the mountain territory, and poor road network especially in the central, mountain to high-mountain sector. In fact, villages are located mostly in the external sectors, and are normally reachable through roads starting from the plain areas surrounding the massif, while only a few roads, today partly inaccessible, cross the massif.

The administrative and territorial fragmentation has also played an important role in the environmental valorization and promotion of the Matese Mountains that until now have been managed in an uncoordinated way by the Campania and Molise regions, each restricted exclusively to their own territorial competences. In this regard, the establishment, in 1993, of the Matese Regional Park (Figure 1), which is entirely located in Campanian territory, represented a fundamental, albeit "partial" step towards the conservation and sustainable fruition of the rich natural heritage of the Matese Mountains. Conversely, the Molise Regional Park did never become a reality, and it took nearly three decades to tackle concretely the Matese National Park project. The latter is finally being set up in recent years, even if with some problems related to its perimetration are still under discussion (see perimeter hypothesis 2019 in Figure 1).

A substantial part of the rich natural heritage of the Matese area is linked to the wide extension of the protected areas, consisting in the Matese Regional Park area and 13 partially overlapping Special Protection Areas (SPAs) and Special Areas of Conservation (SACs) (Figure 1). To this are added the great beauty and diversity of its mountain landscape together with its elevated geological heritage. The Molise portion of the Matese area, in fact, is characterized by the highest density of geosites at the regional scale (macro-area MateseBoiano-Sepino basins, [68]), while a total of 59 geosites are found within the hypothesized perimeter of the Matese National Park (see Figure 1 and below for further details).

Both the biological and geological resources are surely precious and essential for the green growth and sustainable development of the Matese area and, especially, for the success of the future Matese National Park [71], making it a good candidate for future promotion as a Geopark. These resources could contribute, furthermore, to contrast among others the trend to consistent depopulation, also coupled with a net increase of the old-age index, which has affected most of the 37 municipalities of the Matese area documented for the period 1971-2011 [72].

\section{Materials and Methods}

\subsection{Selection and Evaluation of the Geosites}

To define the geoitinerary and select the most suitable geosites for it, we followed the workflow illustrated in Figure 4. All data available for the geosites falling in the hypothesized perimeter of the Matese National Park (Figure 1) were examined. Among various data sources, such as literature, geosite inventories and the data archive of the authors, the main sources of data are represented by the following official geosite inventories/projects (Figure 4): the Geosite Inventory of Molise region [68,73,74], the Italian 
Geosites Inventory of ISPRA [75], and the "Census of geosites and cartography of the geological-environmental itineraries of Campania" project (geosites included in the Geosite Map of Campania [76,77]. Based on the data collected for all geosites, we created a relative database in a GIS environment (Database of the Matese National Park geosites, Figure 4).

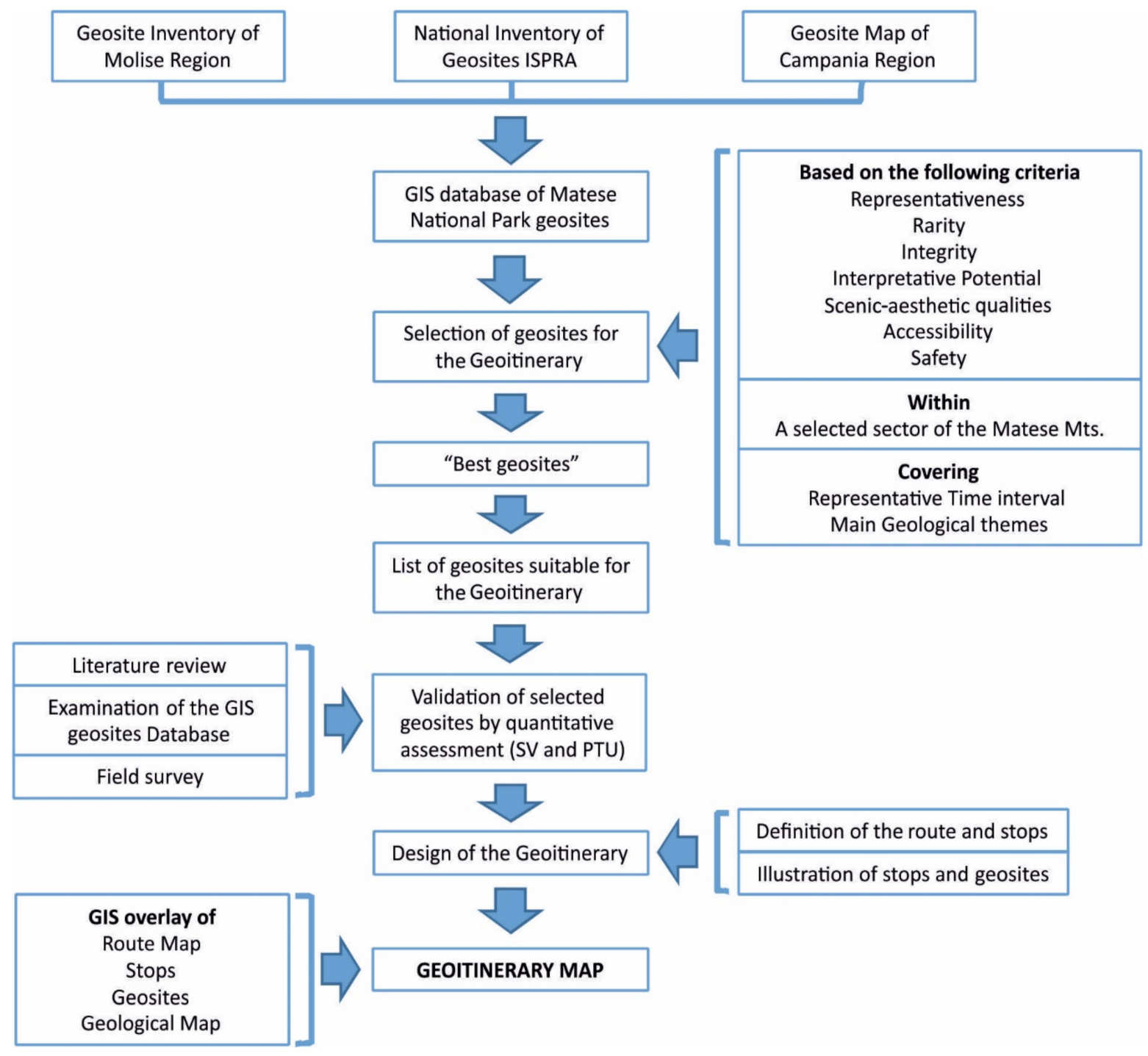

Figure 4. Flow chart showing the criteria and steps used for the design of the geoitinerary, the selection of geosites and the realization of the Geoitinerary Map.

For the Molise geosites, inventory cards containing their description and other information, such as the ages of rock formations and genetic processes involved, the main scientific interests and the relevance of the geosites, are available [74].

For the Campanian geosites included in the Geosite Map of Campania, such cards are not available. Therefore, first information on the Campanian geosites included in our database was mainly extracted from the cards available on the ISPRA website [75] and from literature $[68,78,79]$.

The compilation of the Matese National Park Geosite Database allowed for storing information provided by the consulted data sources, concerning in particular the geological periods covered by the geosites, their primary scientific interests and the main geological themes they deal with.

Compatibly with this information and the overall distribution of geosites, we have individuated an area particularly representative as regards the geological and geomorpho- 
logical aspects of greatest importance of the Matese massif, where to individuate the "best geosites" for the geoitinerary.

Regarding the selection of the "best geosites", we used an integrated approach, based on several criteria. Starting conditions were that the proposed itinerary could best describe major steps of the geological and geomorphological evolution of the Matese massif involving geosites that cover significant time intervals in this sense and can excellently illustrate the main geological themes identified.

To ascertain the scientific value of these geosites, we took into account the criteria Representativeness, Rarity and Integrity (present conservation status) which are widely used worldwide (e.g., [80-89]). Furthermore, we considered the selection criteria Safety, Accessibility, Scenic-aesthetic qualities and Interpretative potential, which are essential for assessing sites suitable for geotourism use (e.g., [77,89]). Particularly, the scenic-aesthetic qualities and the interpretative potential of geosites are important features to approach a wide audience and to disseminate geological information to non-geologists. Therefore, in order to avoid duplications, in cases of two or more geosites illustrating similar geological features or geomorphological processes, having all other values approximately equal, we selected the one with the highest interpretative potential and scenic-aesthetic appeal.

In addition, the necessary movements from site to site were considered and the connection between sites through a route was ensured. Based on this comparative analysis, we selected 16 geosites for the itinerary.

However, such analyses and related geosite evaluations can be considered not sufficient or may imply errors, as the used information derives from different inventories, which are based on different evaluation methods, essentially qualitative for the Campanian geosites [90] but quantitative instead for the Molise geosites [68].

Therefore, to have an evaluation be valid equally for all selected geosites, allowing the possibility of a real comparison between geosites, we have subjected them to a new quantitative assessment procedure. According to Mucivuna et al. 2022 [91], to evaluate the scientific value of geosites, in the absence of specific features to be evaluated (as, for example, in the case of urban or underwater sites), instead of creating new methods, the use of existing, validated methods is preferable as a priorityand, specifically, that of general-purpose quantitative methods that can be applied well to both geosites and geomorphosites. Therefore, considering the features of the Matese geosites, among the many methods developed (e.g., Mucivuna et al., 2019 [92], and reference therein), we have chosen to use the one proposed by Brilha 2016 [86]. This method is a widely used general-purpose method that allows for deriving the scientific value (SV) and Potential Tourist Use (PTU) of geosites, providing a maximum achievable value of 400 for each index.

We based the assessment of SV and PTU on the data provided by our GIS geosite database coupled with a detailed literature review and, where appropriate, new field surveys. Regarding in particular the parameters/criteria used for the PTU assessment, we integrated these data with those extractable from geothematic sources and statistical databases of regional or national archives available online such as those provided by the ISTAT [93].

Based on the scores of SV, in agreement with [89], we attributed an international or national relevance to geosites with values equal to or greater than 300 and equal to or greater than 200, respectively. To geosites with SV less than 200 (geodiversity sites sensu Brilha 2016 [86], and Prosser et al. 2010 [94] in Albani et al. 2020 [89]), we attributed a regional relevance.

\subsection{Design and Illustration of the Geoitinerary}

Once assessed their SV and PTU and, therefore, having validated the 16 geosites, we designed the geoitinerary by identifying the stops allowing on-site and/or panoramic views at one or more geosites, and tracing the route also through field surveys.

To illustrate the geoitinerary, a map was drawn in GIS environment by overlaying a simplified geological map with other informative layers created on purpose containing 
the route, the stops and the geosites, respectively. The geological map contains all the basic geological information to facilitate the understanding of the main geological features illustrated by the geosites by a broad audience. The base of this map is a hillshade model derived from a $40 \mathrm{~m}$ resolution Digital Elevation Model (DEM).

To visualize their "spatial-temporal position" within the Matese geological framework, the stops were located both on a stratigraphic column and on two cross-sections included in the geoitinerary map. The geological cross-sections are simplified to ideally represent the stratigraphic and tectonic setting and to emphasize particular geological aspects encountered along the itinerary.

Furthermore, a synthetic view of the stops, reporting the names of related geosites, the main geological themes they illustrate and the time intervals they cover, was also prepared. Finally, to make it possible to enjoy the itinerary independently and without a guide, we prepared descriptive cards for each stop. These descriptive cards have been enriched with specific illustrative material consisting in photos, geological sketches, 3D schemes and more, depending on the case, to facilitate the disclosure of geosites and their understanding by people without a geological background.

\section{Results}

\subsection{The Matese National Park Geosite Database}

Our Matese National Park Geosite Database contains 59 geosites (Figure 1). The 34 geosites located in the Molise sector are all included in the regional inventory and 16 of them are also present in the ISPRA Italian Geosites Inventory. The other 25 geosites are located in the Campanian sector. Twelve of these geosites are included both in the Geosite Map of Campania and in the ISPRA Geosites Inventory, 11 geosites are included only in the Geosite Map of Campania and other 2 only in the ISPRA Inventory.

These geosites cover an overall time interval from the Mesozoic to Quaternary. Their primary scientific interests (Figure 5) are Geomorphology (more than half of the geosites are geomorphosites), Stratigraphy, Paleontology and Structural Geology, but also Hydrogeology and Geomining are represented. In addition, these geosites can be linked to one or more of the following geological themes: Paleogeography, Tectonics, Hydrogeology, Karst, Long-term landscape evolution, Paleoclimate, Active morphodynamics and Geohistory. Regarding the geosites related to the Geohistory theme, we mean geosites that contribute to/have a meaning for the history of geology [95].

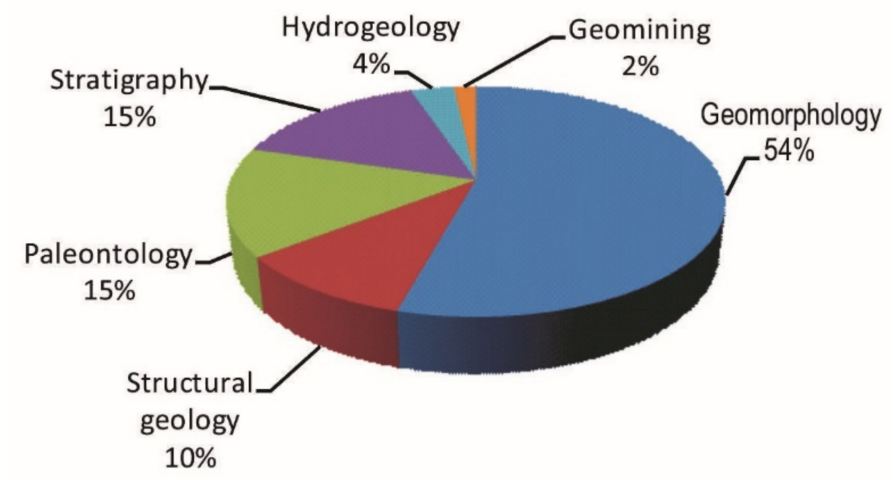

Figure 5. Primary scientific interests and relative percentages of the Matese National Park geosites.

\subsection{The Geosites Selected for the Geoitinerary}

We have selected 16 geosites for the geoitinerary (Figure 6; Table 1). Some of these geosites have already been included in other itineraries [50-53] and/or the subject of specific excursions dedicated to geology specialists [96].

Consistent with the presence of numerous geomorphological geosites (54\%) within the Matese National Park Geosite Database, the majority of the 16 selected geosites, precisely ten of them, are geomorphosites. There are, however, also three paleontological geosites, 
two stratigraphical ones and a geomining geosite. Four of these geosites refer to the Cretaceous, one to the Cretaceous and the Miocene, and eleven to the Pleistocene and Holocene. All the major geological themes of the Matese National Park Geosite Database listed above are embraced by these geosites. In fact, many of them cover more than one of the topics listed above, with the Regia Piana Bauxite Mines covering even five themes. Based on the recurring themes, two main geosite groups can be distinguished: a group made of 5 geosites that are tightly linked to the theme Paleogeography, and a group of 11 geosites that are mainly an expression of the Long-term landscape evolution.

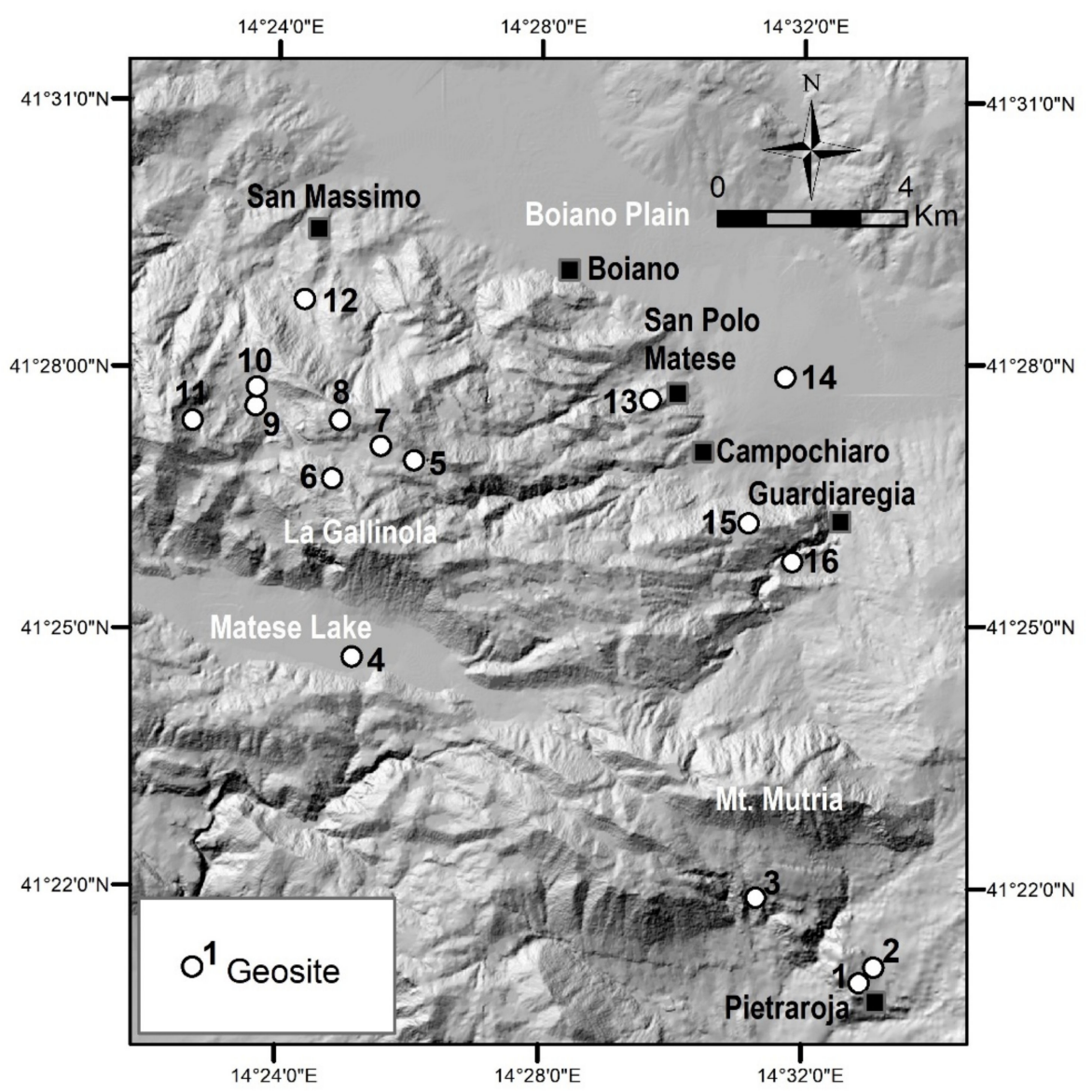

Figure 6. Location of the 16 selected geosites (the location of the area is shown in Figure 2). 1 = Fossiliferous limestones of Pietraroja (Le Cavere); 2 = Cava Canale; 3 = Regia Piana Bauxite Mines; 4 = Matese Lake polje; 5 = La Costa Alta fossiliferous limestones; $6=$ La Gallinola fault slope; 7 = Campo Puzzo polje; 8 = Serra Le Tre Finestre karst surface; 9 = Campitello Matese polje; 10 = Campitello Matese moraine deposits; $11=$ Mt. Miletto glacialcirques; $12=$ Lacustrine deposits of San Massimo; 13 = San Polo Matese rudist limestones; 14 = Campochiaro alluvial fan; 15 = Costa della Defenza fault slope; 16 = Quirino gorge.

Among the five geosites included in the first group (Figure 7), four sites are also an expression of the theme Geohistory. In particular, the San Polo Matese rudist limestones geosite (13 in Figure 6 and Table 1, Figure 7e) allows for observing Upper Cretaceous limestones rich in rudist fossils, partly in position of growth, that indicate an open-marginal shelf environment ([97] and reference therein). This geosite is located in the northern central sector of the Matese Mountains and known in the geological-paleontological literature since 1901 [98]. The other three geosites (1, 2 and 3 in Figure 6 and Table 1) are instead located in the southeastern sector of the Matese Park area. Here, one of the first Mesozoic type sequences of the Southern Apennines has been described [99] and three important successions (the Cusano, Longano and Pietraroja formations) referable to the Southern Apennines Miocene transgression have been defined by Selli in 1957 [100]. Among them, 
the Fossiliferous limestones of Pietraroja (Le Cavere) site (1 in Figure 6 and Table 1; Figure 7a,b) certainly stands out, known since the end of the eighteenth century [55] for its paleontological richness. This geosite, given its very high scientific interest, is nowadays protected by a fence and managed by the Ente Geopaleontologico di Pietraroja whose aims are to protect and enhance it. This Lower Cretaceous limestone outcrop contains exceptionally well-preserved fossil fishes (Figure $7 \mathrm{~b}$ ), amphibians and reptiles, but became most famous for the discovery of Scipionix sammiticus [101], a juvenile theropod dinosaur with an exceptional soft tissue preservation. This very didactic geosite is an excellent testimony of the Lower Cretaceous environments that established in this sector of the Southern Apennines, and indicative for thetropical-subtropical shallow water carbonate domains that bordered emergent isolated lands in the Cretaceous Tethys ([96] and reference therein). The other two geosites are equally noteworthy. The Cava Canale geosite ( 2 in Figure 6 and Table 1) offers a superb three-dimensional exposition of the Miocene transgression in the Southern Apennines. In particular, it allows good observation of the Lower Cretaceous limestones overlain by the sediments of the Cusano Formation [100] (Figure 7c), Burdigalian-Langhian in age [102,103], referred to an open carbonate platform temperate neritic environment [62]. Finally, the Regia Piana Bauxite Mines geosite ( 3 in Figure 6 and Table 1) allows the exceptional observation of bauxite deposits (Figure $7 \mathrm{~d}$ ) in correspondence of a Cretaceous stratigraphic gap that characterizes in a unique way the Southern Apennines Mesozoic carbonate platform successions. These continental deposits formed above a karst surface between the Lower and Upper Cretaceous [97,99] under tropical to subtropical climate conditions, to testify clearly repeated long-lasting phases of emersion that affected the Lower Cretaceous carbonate platform in the Southern Apennines [104]. This site is also of geomining interest as it preserves several traces of the mining activities (such as mining tunnels, Figure 7d) that were carried out during the periods 1919-1925 and 1939-1965 [105].

Table 1. Main features of selected geosites. Number (see location in Figure 6) and name of geosite. Primary (1) and secondary (2) scientific interests, geological themes, ages of rock formations (AR) and ages of genetic processes (AGP). Paleontology = Pa; Stratigraphy = St; Sedimentology = Se; Geomorphology = Gm; Geomining = Gmi; Structural Geology = SG; Hydrogeology = H; Pedology = Pe; Palogeography = Pgeo; Geohistory = Ghis; Paleoclimate $=$ Pcli; Tectonics $=\mathrm{T}$; Karst $=$ K; Longterm landscape evolution = LsEv; Active morphodynamics = Amd; Lower Cretaceous $=$ LCret; Upper Cretaceous = UCret; Lower-Middle Miocene = L-MMio; Lower Pleistocene = LP; Middle Pleistocene $=$ MP; Upper Pleistocene $=\mathrm{UP} ;$ Pleistocene-Holocene $=\mathrm{P}-\mathrm{H} ;$ Holocene $=\mathrm{H}$.

\begin{tabular}{|c|c|c|c|c|}
\hline Geosite & Scientific Interests & Geological Themes & AR & AGP \\
\hline $1^{\wedge *}$ Fossiliferous limestones of Pietraroja & $\mathrm{Pa}(1), \mathrm{St}(2), \mathrm{Se}(2)$ & Pgeo, Ghis, Pcli & LCret & - \\
\hline $2^{\wedge *}$ Cava Canale & $\mathrm{St}(1), \mathrm{Pa}(2), \mathrm{Gm}(2)$ & Pgeo, Ghis & $\begin{array}{c}\text { LCret } \\
\text { L-MMio }\end{array}$ & - \\
\hline $3^{\wedge *}$ Regia Piana Bauxite Mines & $\begin{array}{c}\text { Gmi(1), } \mathrm{Gm}(2), \operatorname{St}(2), \mathrm{SG}(2), \\
\mathrm{Pa}(2), \mathrm{Se}(2)\end{array}$ & Pgeo, Ghis, Pcli, T, K & $\begin{array}{l}\text { LCret } \\
\text { UCret }\end{array}$ & - \\
\hline $4^{\wedge *}$ Matese Lake polje & $\mathrm{Gm}(1), \mathrm{SG}(2), \mathrm{H}(2)$ & $\mathrm{K}, \mathrm{H}, \mathrm{LsEv}, \mathrm{T}$ & - & MP-H \\
\hline $5^{\circ *}$ La Costa Alta fossiliferous limestones & $\mathrm{Pa}(1), \mathrm{St}(2)$ & Pgeo & UCret & - \\
\hline $6^{\circ}$ La Gallinola fault slope & $\mathrm{Gm}(1), \mathrm{SG}(2)$ & LaEv, Amd & - & MP-H \\
\hline $7^{\circ *}$ Campo Puzzo polje & $\operatorname{Gm}(1), \operatorname{Pe}(2)$ & $\mathrm{K}, \mathrm{T}, \mathrm{LsEv}$ & - & MP-H \\
\hline $8^{\circ}$ Serra Le Tre Finestre karst surface & $\mathrm{Gm}(1), \mathrm{Pa}(2), \mathrm{Pe}(2)$ & $\mathrm{K}, \mathrm{LsEv}, \mathrm{T}$ & - & LP-H \\
\hline $9^{\circ *}$ Campitello Matese polje & $\mathrm{Gm}(1)$ & $\mathrm{K}, \mathrm{H}, \mathrm{LsEv}, \mathrm{T}$ & - & MP-H \\
\hline $10^{\circ *}$ Campitello Matese moraine deposits & $\mathrm{Gm}(1), \mathrm{St}(2)$ & Pcli, LsEv & UP & - \\
\hline $11^{\circ *}$ Mt. Miletto glacial cirques & $\mathrm{Gm}(1)$ & Pcli, LsEv, Amd & - & MP-UP \\
\hline $12^{\circ}$ Lacustrine deposits of San Massimo & $\mathrm{St}(1), \mathrm{Gm}(2), \mathrm{SG}(2)$ & LsEv, Pgeo, Pcli & MP & - \\
\hline $13^{\circ *}$ San Polo Matese rudist limestones & $\mathrm{Pa}(1), \mathrm{St}(2)$ & Pgeo, Ghis & UCret & - \\
\hline $14^{\circ}$ Costa della Defenza fault slope & $\mathrm{Gm}(1), \mathrm{St}(2)$ & LsEv, Pcli, T & - & MP-H \\
\hline $15^{\circ *}$ Campochiaro alluvial fan & $\mathrm{Gm}(1), \mathrm{SG}(2)$ & LsEv, T & - & UP-H \\
\hline $16^{\circ *}$ Quirino Gorge & $\mathrm{Gm}(1), \mathrm{SG}(2), \mathrm{H}(2)$ & LsEv, T & - & $\mathrm{MP}$ \\
\hline
\end{tabular}

* Geosite included in the ISPRA Geosite Inventory; ${ }^{\wedge}$ Geosite included in the Geosite Map of Campania; ${ }^{\circ}$ Geosite included in the Molise Geosite Inventory. 

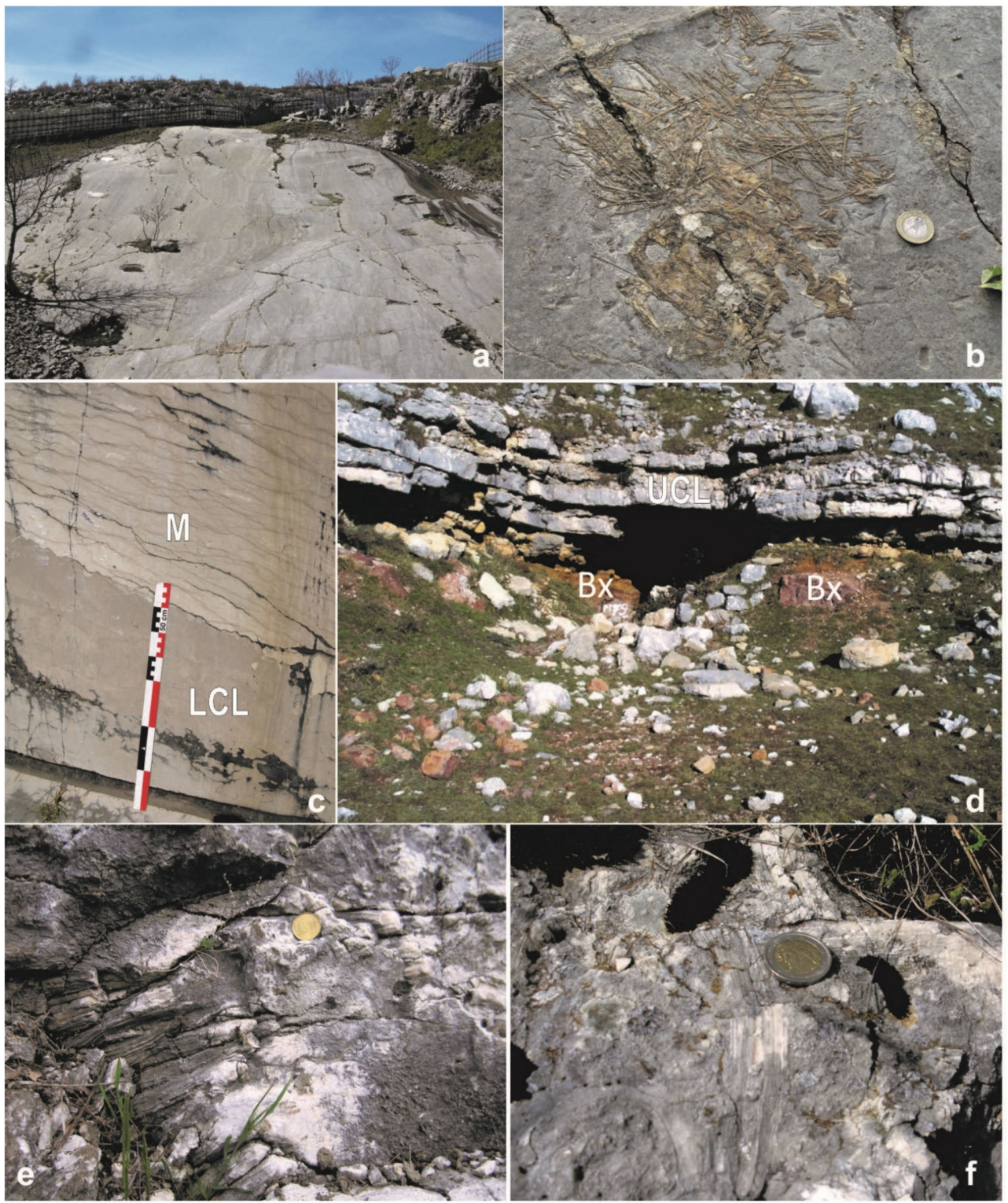

Figure 7. (a) Panoramic view of the Pietraroja fossiliferous limestones geosite (Le Cavere); (b) One of the fish fossils visible at Pietraroja site; (c) Lower Cretaceous limestones (LCL) overlain by the Miocene Cusano Formation (M) visible at Cava Canale; (d) Bauxite mining tunnel in the Regia Piana area excavated along the contact between the bauxite deposits (Bx) and the overlyingUpper Cretaceous limestones (ULC); (e) Detail of the Hippurites colliciatus (Woodward) Reef at San Polo Matese; (f) Detail of the La Costa Alta limestones with rudists.

Within the second group, made of 11 geosites linked to the theme Long-term landscape evolution, four sites are also expression of the topics Karst and Tectonics. The first one is represented by the Serra Le Tre Finestre karst surface geosite (8 in Figure 6 and Table 1; Figure 8a), a surface with a typical karst hummocky morphology generated by the widespread presence of active and inactive dolines as well as open or closed karst depressions, which appear frequently aligned according to NW-SE oriented tectonic lineaments $[68,70]$. The other three geosites are represented by structurally controlled poljes (4, 7 and 9 in Figure 6 and Table 1), generated during Quaternary extensional tectonics and related block-faulting [70]. Among them, the Matese Lake polje (4 in Figure 6 and Table 1; Figure 8b,c) and the Campitello Matese polje geosites (9 in Figure 6 and Table 1; Figure 8d) are also good expressions of the Hydrogeology theme. The Matese Lake polje, which is the largest polje of the Matese area, is mainly controlled by WNW-ESE normal faults [70]. 
This very didactic geosite allows easy observation of numerous geological and geomorphological features. Among the latter, noteworthy are the fault slopes bordering the Matese Lake to the north and the related hanging valleys of fluviokarst origin [70] (Figure 8c), at least two generations of alluvial fans dated to the Late Pleistocene-Holocene [106] and two ponors found along its southern edge (the Scennerato and Brecce ponors). The Matese Lake area is the largest endorheic area $\left(45 \mathrm{~km}^{2}\right)$ of the Massif. It contributes significantly to the recharge of the Matese aquifer and is believed to supply the Maretto and Torano springs located along its southern slopes [107] (Figure 2). In particular, the connection between the Scennerato ponor and the Torano spring has been demonstrated [108,109].

The Campitello Matese polje geosite (Figure 8d) is an active polje, mainly controlled by NW-SE tectonic lineaments. This geosite well illustrates how closely its morphology and hydrology are related with extensional tectonics and karst drainage [68]. In particular, on its floor, which is covered prevailingly by alluvial and moraine deposits of Late Pleistocene-Holocene age [106,110], a couple of ponors ensuring the endorheic drainage are easily observable.

Other three geosites of the second group host also important evidence linked to the Paleoclimate theme. The first two illustrate relict glacial landforms. One is the Mt. Miletto glacial cirques geosite (11 in Figure 6 and Table 1), which consists of two armchair-shaped glacial cirques, the so-called Circo Maggiore (major cirque) and the S. Nicola cirque (Figure 8e). The Circo Maggiore, which is the larger and better preserved cirque, placed a few hundreds of meters higher up with respect to the S. Nicola cirque, has been referred to the Last Glacial Maximum [70]. The other one is the Campitello Matese moraine deposits geosite (10 in Figure 6 and Table 1), referred to the Late Glacial Maximum [69,111], a very suitable site to illustrate the typical features of glacial deposits (Figure 8f). The third site is the Lacustrine deposits of San Massimo geosite (12 in Figure 6 and Table 1), consisting of a relatively small outcrop located along Serra San Giorgio. This outcrop exposes terraced fluvial-lacustrine deposits [112] (Figure 8g), testifying an ancient lake, Middle Pleistocene in age $[64,113]$, along with some moraine deposits (Figure $8 \mathrm{~h}$ ) pre-Last Glacial in age [70], overlying the fluvial-lacustrine succession.

Returning to the Mt. Miletto glacial cirques geosite, this also embraces the topic Active morphodynamics. The steep headwalls of the cirques, in fact, are partially covered by active scree slopes produced by cryoclastic processes and associated termoclastic phenomena, which typically reflect the climate conditions that currently characterize the Apennines high mountain areas.

Finally, the last four geosites of this group are also linked to the theme of tectonics. Two of them are represented by structural landforms, the La Gallinola fault slope (6 in Figure 6 and Table 1), and the Coste della Defenza fault slope (15 in Figure 6 and Table 1) geosites, the first being located in the inner high mountain area, the second along the northern front of the Matese massif. The La Gallinola fault slope geosite (Figure 9a) is the result of Pleistocene tectonic uplift and block-faulting, and shows typical geomorphological features such as its rectilinear profile resulting from long-term processes of slope replacement under periglacial conditions. Its footslope and lower backslope are covered by partly still active scree slopes and debris cones, testifying the active morphodynamics affecting the slope related to ongoing intense cryoclastic degradation. The Coste della Defenza fault slope (Figure 9b) is evidence of the tectonic uplift that has affected the northern Matese flanks bordering the Boiano basin that, conversely, was affected by tectonic subsidence. The genesis of this E-W trending slope is related to a Pleistocene normal fault [64,114], which also shows evidence of historical to recent activity and is believed to be one of the most hazardous seismogenic structures of Europe [64].

The other two, the Quirino gorge (16 in Figure 6 and Table 1) and the Campochiaro alluvial fan (14 in Figure 6 and Table 1) geosites, are instead fluvial landforms controlled by tectonics. The Quirino gorge geosite (Figure 9c) is a didactic example of a superimposed, deep and narrow gorge [68] that was incised by the Quirino Stream during the Middle Pleistocene uplift of the Matese massif. Finally, the Campochiaro alluvial fan geosite (Figure 9d) shows the typical features 
of Apennine alluvial fan deposits laid down by major streams near the mountain fronts under the influence of tectonic uplift and climate [68] during Late Pleistocene cold periods $[64,115,116]$.

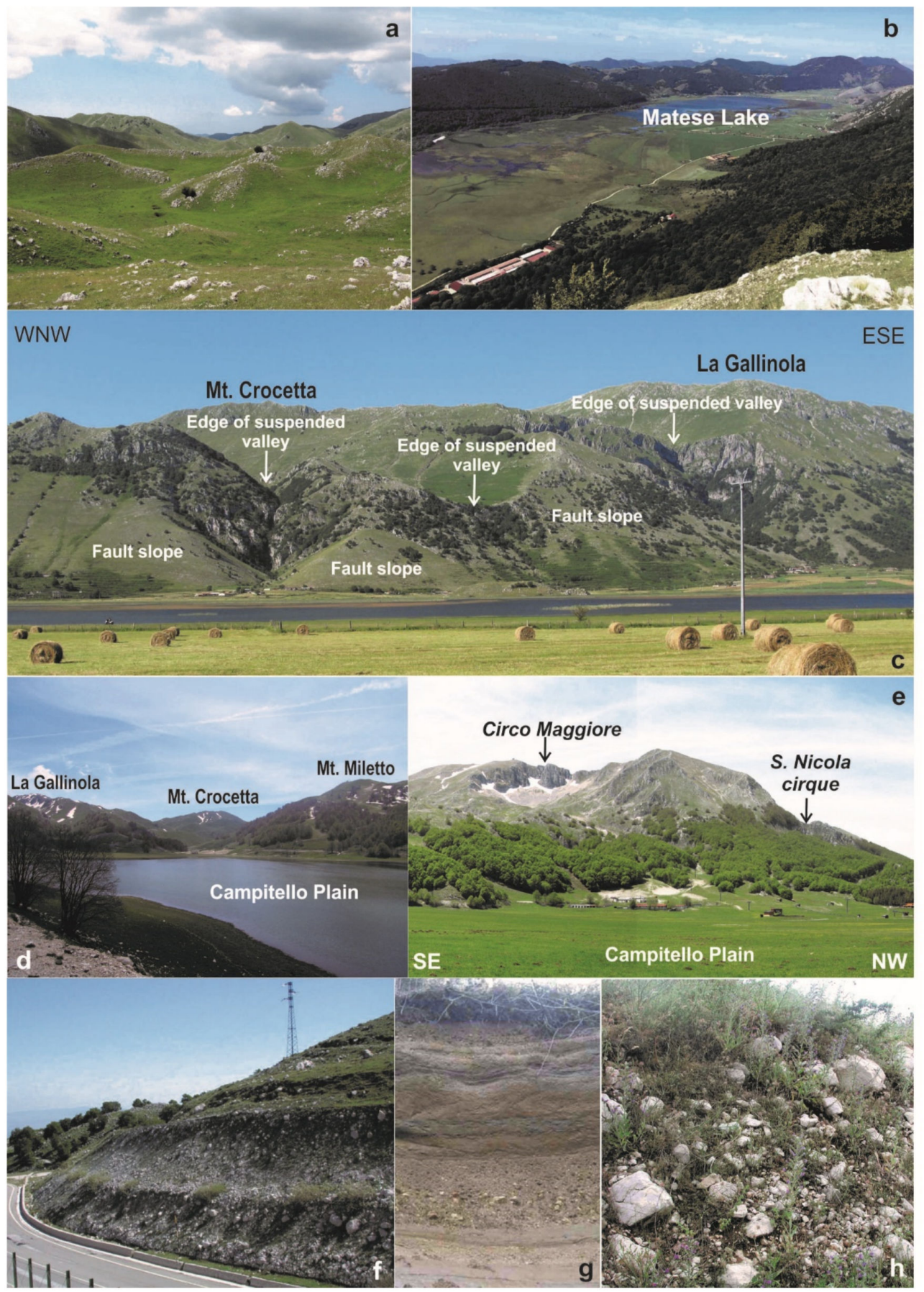

Figure 8. (a) Detail of the Serra Le Tre Finestre surface showing several solution dolines; (b) Panoramic view of the Matese Lake basin seen from La Gallinola; (c) View of the fault slopes of Mt. Crocetta and La Gallinola, bordering the Matese Lake polje to the north and of the edges of some ancient suspended valleys of fluviokarst origin; (d) The Campitello Matese polje typically flooded during spring; (e) The Circo Maggiore (major cirque) of Mt. Miletto and the S. Nicola cirque; (f) The Campitello Matese moraine deposits; (g) Detail of the laminated fluvio-lacustrine deposits of San Massimo, made of silts and clays with interbedded reworked volcaniclastic material and rounded pebbles; (h) Detail of the Middle Pleistocene glacial deposits overlying the S. Massimo lacustrine deposits, made of angular to subangular heterometric, calcareous clasts in sandy-silty matrix. 

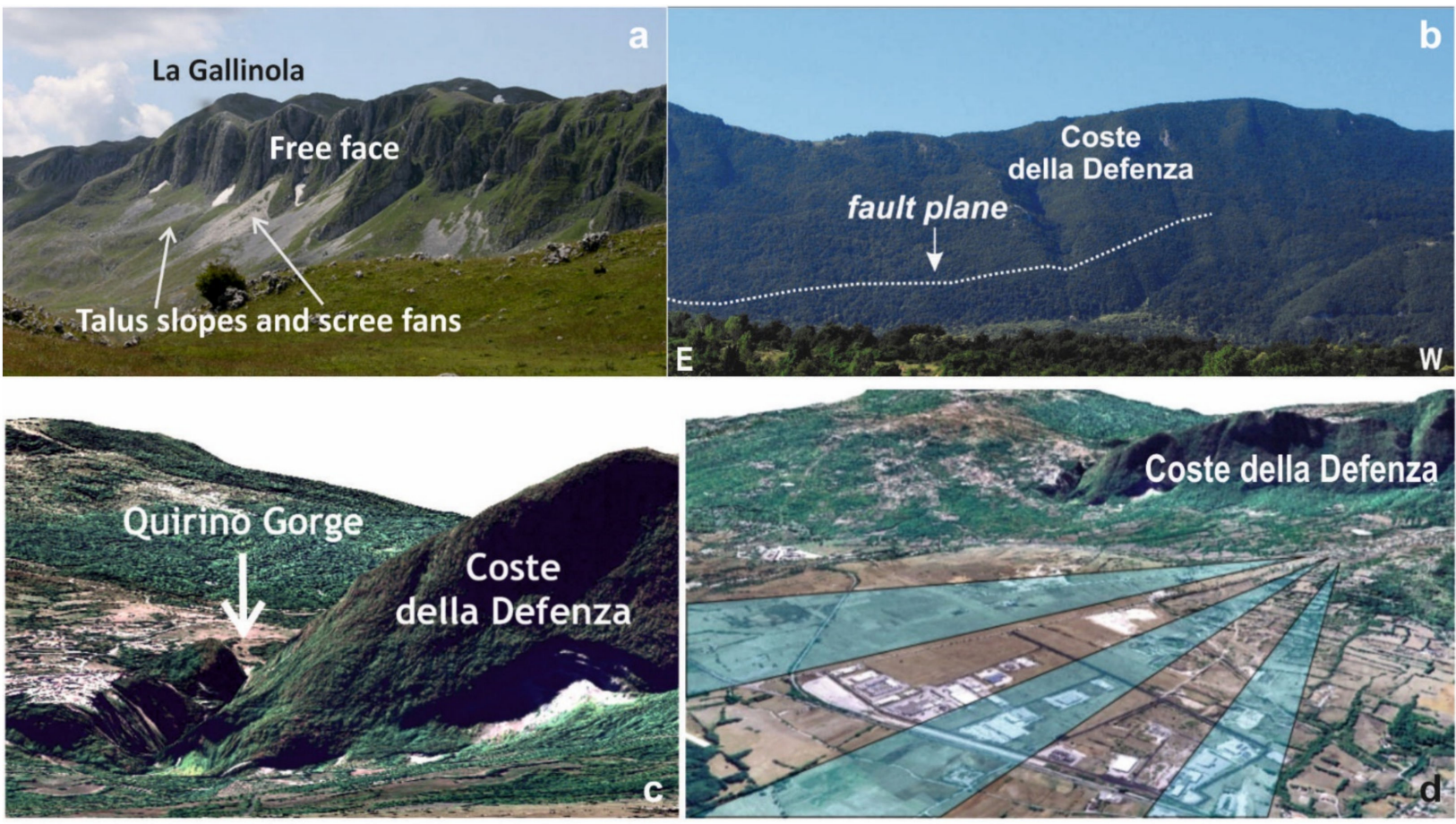

Figure 9. (a) The La Gallinola fault slope; (b) The Costa della Defenza fault slope; (c) The Quirino Stream gorge on 3D scene; (d) The Campochiaro alluvial fan on 3D scene.

\subsection{SV and PTU of the Selected Geosites}

The quantitative assessment of the Scientific Value (SV) carried out for the selected geosites has provided for them values ranging between 150 and 325 (Table 2).

Table 2. Weights, scores and values attributed to the criteria used to assess the Scientific Value of the selected geosites. $\mathrm{Rp}=$ Representativeness; $\mathrm{KL}=$ Key locality; SK = Scientific knowledge; I = Integrity; $\mathrm{GD}=$ Geological diversity; RR = Rarity; UL = Use limitation. The total SV value and the relevance of each geosite are also shown.

\begin{tabular}{|c|c|c|c|c|c|c|c|c|c|c|}
\hline \multicolumn{11}{|c|}{ Scientific Value (SV) } \\
\hline \multirow{2}{*}{ Geosite } & Criterion & $\mathrm{Rp}$ & KL & SK & I & GD & $\mathbf{R R}$ & UL & Total & Relevance \\
\hline & Weight & $30 \%$ & $20 \%$ & $5 \%$ & $15 \%$ & $5 \%$ & $15 \%$ & $10 \%$ & Value & Relevance \\
\hline \multirow{2}{*}{$\begin{array}{l}\text { Fossiliferous limestones of } \\
\text { Pietraroja (Le Cavere) }\end{array}$} & score & 4 & 2 & 4 & 4 & 1 & 4 & 2 & - & - \\
\hline & value & 120 & 40 & 20 & 60 & 5 & 60 & 20 & 325 & International \\
\hline \multirow{2}{*}{ Cava Canale } & score & 4 & 1 & 4 & 4 & 2 & 1 & 4 & - & - \\
\hline & value & 120 & 20 & 20 & 60 & 10 & 15 & 40 & 285 & National \\
\hline \multirow{2}{*}{ Regia Piana Bauxite Mines } & score & 4 & 1 & 4 & 2 & 1 & 4 & 4 & - & - \\
\hline & value & 120 & 20 & 20 & 30 & 5 & 60 & 40 & 295 & National \\
\hline \multirow{2}{*}{ Matese Lake polje } & score & 4 & 1 & 4 & 4 & 4 & 0 & 4 & - & - \\
\hline & value & 120 & 20 & 20 & 60 & 20 & 0 & 40 & 280 & National \\
\hline \multirow{2}{*}{ La Costa Alta fossiliferous limestones } & score & 1 & 0 & 4 & 4 & 1 & 0 & 4 & - & - \\
\hline & value & 30 & 0 & 20 & 60 & 5 & 0 & 40 & 155 & Regional \\
\hline \multirow{2}{*}{ La Gallinola fault slope } & score & 1 & 0 & 4 & 4 & 4 & 0 & 4 & - & - \\
\hline & value & 30 & 0 & 20 & 60 & 20 & 0 & 40 & 170 & Regional \\
\hline
\end{tabular}


Table 2. Cont.

\begin{tabular}{|c|c|c|c|c|c|c|c|c|c|c|}
\hline \multicolumn{11}{|c|}{ Scientific Value (SV) } \\
\hline \multirow{2}{*}{ Geosite } & Criterion & $\mathbf{R p}$ & KL & SK & I & GD & RR & UL & Total & Relevance \\
\hline & Weight & $30 \%$ & $20 \%$ & $5 \%$ & $15 \%$ & $5 \%$ & $15 \%$ & $10 \%$ & Value & Relevance \\
\hline \multirow{2}{*}{ Campo Puzzo polje } & score & 1 & 0 & 2 & 4 & 2 & 0 & 4 & - & - \\
\hline & value & 30 & 0 & 10 & 60 & 10 & 0 & 40 & 150 & Regional \\
\hline \multirow{2}{*}{ Serra Le Tre Finestre karst surface } & score & 1 & 0 & 2 & 4 & 1 & 1 & 4 & - & - \\
\hline & value & 30 & 0 & 10 & 60 & 5 & 15 & 40 & 160 & Regional \\
\hline \multirow{2}{*}{ Campitello Matese polje } & score & 1 & 0 & 4 & 4 & 4 & 0 & 4 & - & - \\
\hline & value & 30 & 0 & 20 & 60 & 20 & 0 & 40 & 170 & Regional \\
\hline \multirow{2}{*}{ Campitello Matese moraine deposits } & score & 1 & 0 & 4 & 2 & 1 & 2 & 4 & - & - \\
\hline & value & 30 & 0 & 20 & 30 & 5 & 30 & 40 & 155 & Regional \\
\hline \multirow{2}{*}{ Mt. Miletto glacial cirques } & score & 2 & 0 & 4 & 4 & 1 & 1 & 2 & - & - \\
\hline & value & 60 & 0 & 20 & 60 & 5 & 15 & 20 & 180 & Regional \\
\hline \multirow{2}{*}{ Lacustrine deposits of San Massimo } & score & 1 & 1 & 4 & 1 & 2 & 2 & 4 & - & - \\
\hline & value & 30 & 20 & 20 & 15 & 10 & 30 & 40 & 165 & Regional \\
\hline \multirow{2}{*}{ San Polo Matese rudist limestones } & score & 1 & 2 & 4 & 2 & 0 & 2 & 2 & - & - \\
\hline & value & 30 & 40 & 20 & 30 & 0 & 30 & 20 & 170 & Regional \\
\hline \multirow{2}{*}{ Costa della Defenza fault slope } & score & 1 & 1 & 4 & 4 & 2 & 0 & 4 & - & - \\
\hline & value & 30 & 20 & 20 & 60 & 10 & 0 & 40 & 180 & Regional \\
\hline \multirow{2}{*}{ Campochiaro alluvial fan } & score & 1 & 1 & 4 & 4 & 1 & 1 & 2 & - & - \\
\hline & value & 30 & 20 & 20 & 60 & 5 & 15 & 20 & 170 & Regional \\
\hline \multirow{2}{*}{ Quirino Gorge } & score & 1 & 0 & 4 & 4 & 2 & 0 & 4 & - & - \\
\hline & value & 30 & 0 & 20 & 60 & 10 & 0 & 40 & 160 & Regional \\
\hline
\end{tabular}

In particular, a maximum SV of 325 was attributed to the Fossiliferous limestones of Pietraroja (Le Cavere) geosite, confirming its prominent position and highlighting its international relevance (Table 2). For the other three geosites, we achieved instead a national relevance. Among these, the Regia Piana Bauxite Mines geosite has the highest SV (295), due to its maximum score for the Rarity criterion that compensates the lower scores obtained for the Integrity and Geological Diversity criteria. The remaining twelve geosites obtained SV values less than 200, and therefore are considered of regional relevance. Among them, the highest scientific values were achieved by the Mt. Miletto glacial cirques and the Costa della Defenza fault slope geosites (SV = 180, Table 2), while the Campo Puzzo polje geosite obtained the lowest SV (150). The high scientific value of the Mt. Miletto glacial cirques geosite is mainly determined by the high scores of the Integrity and Scientific knowledge criteria combined with the average score of the Representativeness criterion. The high SV of Costa della Defenza fault slope geosite, in addition to the high scores of the Integrity and Scientific knowledge criteria, is linked also to the high score of the Use limitations criterion. Instead, the null scores of the Key locality and Rarity criteria, the average scores of the Scientific knowledge and Geological diversity criteria as well as the low score of Representativeness criterion, essentially determined the low SV of the CampoPuzzo polje geosite.

The PTU values calculated for the selected geosites range between a maximum of 350 and a minimum of 195 (Table 3). In particular, the best PTU values have been reached by the geosites Fossiliferous limestones of Pietraroja (Le Cavere), Matese Lake polje and Campitello Matese polje (respectively 350, 300 and 295 in Table 3). The lowest PTU value of 195 was attributed instead to the Lacustrine deposits of San Massimo geosite. With exception to the 
latter, all other geosites reached PTU values equal to or greater than 230, highlighting a relatively good to very high tourist potential.

Table 3. Weights, scores and values attributed to the criteria used to assess the Potential Tourist Use, and total PTU values of selected geosites. V = Vulnerability; $\mathrm{A}=$ Accessibility; UL = Use limitations; $\mathrm{Sa}=$ Safety $; \mathrm{L}=$ Logistics; $\mathrm{Pd}=$ Population density; As = Association with other values; $\mathrm{Sc}=$ Scenery; $\mathrm{Un}=$ Uniqueness; $\mathrm{O}=$ Observation conditions; IP = Interpretative Potential; E = Economic level; RA $=$ Proximity of recreational areas.

\section{Potential Tourist Use (PTU)}

\begin{tabular}{|c|c|c|c|c|c|c|c|c|c|c|c|c|c|c|c|}
\hline Geosite & $\begin{array}{l}\text { Criterion } \\
\text { Weight }\end{array}$ & $\begin{array}{c}V \\
10 \%\end{array}$ & $\begin{array}{c}\mathrm{A} \\
10 \%\end{array}$ & $\begin{array}{l}\text { UL } \\
5 \%\end{array}$ & $\begin{array}{l}\text { Sa } \\
10 \%\end{array}$ & $\begin{array}{c}\mathrm{L} \\
5 \%\end{array}$ & $\begin{array}{l}P d \\
5 \%\end{array}$ & $\begin{array}{l}\text { As } \\
5 \%\end{array}$ & $\begin{array}{l}\text { Sc } \\
15 \%\end{array}$ & $\begin{array}{l}\text { Un } \\
10 \%\end{array}$ & $\begin{array}{c}\mathrm{O} \\
5 \%\end{array}$ & $\begin{array}{l}\text { IP } \\
10 \%\end{array}$ & $\begin{array}{c}E \\
5 \%\end{array}$ & $\begin{array}{l}\text { RA } \\
5 \%\end{array}$ & $\begin{array}{l}\text { Total } \\
\text { Value }\end{array}$ \\
\hline \multirow{2}{*}{$\begin{array}{c}\text { Fossiliferous } \\
\text { limestones of Pietraroja } \\
\text { (Le Cavere) }\end{array}$} & score & 4 & 4 & 3 & 3 & 3 & 1 & 4 & 4 & 4 & 4 & 4 & 1 & 4 & - \\
\hline & value & 40 & 40 & 15 & 30 & 15 & 5 & 20 & 60 & 40 & 20 & 40 & 5 & 20 & 350 \\
\hline \multirow{2}{*}{ Cava Canale } & score & 3 & 3 & 4 & 2 & 3 & 1 & 4 & 2 & 2 & 4 & 3 & 1 & 4 & - \\
\hline & value & 30 & 30 & 20 & 20 & 15 & 5 & 20 & 30 & 20 & 20 & 30 & 5 & 20 & 265 \\
\hline \multirow{2}{*}{$\begin{array}{l}\text { Regia Piana } \\
\text { Bauxite Mines }\end{array}$} & score & 3 & 3 & 4 & 2 & 3 & 1 & 3 & 2 & 3 & 4 & 3 & 1 & 4 & - \\
\hline & value & 30 & 30 & 20 & 20 & 15 & 5 & 15 & 30 & 30 & 20 & 30 & 5 & 20 & 270 \\
\hline \multirow{2}{*}{ Matese Lake polje } & score & 3 & 4 & 4 & 2 & 3 & 1 & 4 & 3 & 2 & 4 & 4 & 1 & 4 & - \\
\hline & value & 30 & 40 & 20 & 20 & 15 & 5 & 20 & 45 & 20 & 20 & 40 & 5 & 20 & 300 \\
\hline \multirow{2}{*}{$\begin{array}{l}\text { La Costa Alta } \\
\text { fossiliferous } \\
\text { limestones }\end{array}$} & score & 3 & 3 & 4 & 2 & 4 & 2 & 4 & 0 & 2 & 4 & 4 & 1 & 4 & - \\
\hline & value & 30 & 30 & 20 & 20 & 20 & 10 & 20 & 0 & 20 & 20 & 40 & 5 & 20 & 255 \\
\hline \multirow{2}{*}{ La Gallinola fault slope } & score & 4 & 3 & 4 & 2 & 4 & 2 & 4 & 0 & 1 & 4 & 3 & 1 & 4 & - \\
\hline & value & 40 & 30 & 20 & 20 & 20 & 10 & 20 & 0 & 10 & 20 & 30 & 5 & 20 & 245 \\
\hline \multirow{2}{*}{ Campo Puzzo polje } & score & 3 & 3 & 4 & 2 & 4 & 2 & 4 & 0 & 1 & 4 & 4 & 1 & 4 & - \\
\hline & value & 30 & 30 & 20 & 20 & 20 & 10 & 20 & 0 & 10 & 20 & 40 & 5 & 20 & 245 \\
\hline \multirow{2}{*}{$\begin{array}{c}\text { Serra Le Tre } \\
\text { Finestre karst surface }\end{array}$} & score & 4 & 3 & 4 & 2 & 4 & 2 & 4 & 0 & 1 & 4 & 4 & 1 & 4 & - \\
\hline & value & 40 & 30 & 20 & 20 & 20 & 10 & 20 & 0 & 10 & 20 & 40 & 5 & 20 & 255 \\
\hline \multirow{2}{*}{ Campitello Matese polje } & score & 3 & 4 & 4 & 2 & 4 & 1 & 4 & 3 & 1 & 4 & 4 & 1 & 4 & - \\
\hline & value & 30 & 40 & 20 & 20 & 20 & 5 & 20 & 45 & 10 & 20 & 40 & 5 & 20 & 295 \\
\hline \multirow{2}{*}{$\begin{array}{l}\text { Campitello Matese } \\
\text { moraine deposits }\end{array}$} & score & 2 & 3 & 4 & 2 & 4 & 1 & 4 & 0 & 3 & 3 & 4 & 1 & 4 & - \\
\hline & value & 20 & 30 & 20 & 20 & 20 & 5 & 20 & 0 & 30 & 15 & 40 & 5 & 20 & 245 \\
\hline \multirow{2}{*}{$\begin{array}{l}\text { Mt. Miletto glacial } \\
\text { cirques }\end{array}$} & score & 3 & 0 & 4 & 2 & 4 & 1 & 4 & 2 & 3 & 4 & 4 & 1 & 4 & - \\
\hline & value & 30 & 0 & 20 & 20 & 20 & 5 & 20 & 30 & 30 & 20 & 40 & 5 & 20 & 260 \\
\hline \multirow{2}{*}{$\begin{array}{l}\text { Lacustrine deposits of } \\
\text { San Massimo }\end{array}$} & score & 1 & 3 & 3 & 2 & 4 & 1 & 3 & 0 & 2 & 2 & 3 & 1 & 3 & - \\
\hline & value & 10 & 30 & 15 & 20 & 20 & 5 & 15 & 0 & 20 & 10 & 30 & 5 & 15 & 195 \\
\hline \multirow{2}{*}{$\begin{array}{l}\text { San Polo Matese } \\
\text { rudist limestones }\end{array}$} & score & 2 & 4 & 4 & 2 & 4 & 1 & 4 & 1 & 2 & 4 & 4 & 1 & 3 & - \\
\hline & value & 20 & 40 & 20 & 20 & 20 & 5 & 20 & 15 & 20 & 20 & 40 & 5 & 15 & 260 \\
\hline \multirow{2}{*}{$\begin{array}{l}\text { Costa della Defenza } \\
\text { fault slope }\end{array}$} & score & 3 & 3 & 4 & 2 & 4 & 1 & 4 & 0 & 1 & 4 & 3 & 1 & 4 & - \\
\hline & value & 30 & 30 & 20 & 20 & 20 & 5 & 20 & 0 & 10 & 20 & 30 & 5 & 20 & 230 \\
\hline \multirow{2}{*}{ Campochiaro alluvial fan } & score & 3 & 3 & 4 & 2 & 4 & 1 & 4 & 0 & 1 & 3 & 4 & 1 & 4 & - \\
\hline & value & 30 & 30 & 20 & 20 & 20 & 5 & 20 & 0 & 10 & 15 & 40 & 5 & 20 & 235 \\
\hline \multirow{2}{*}{ Quirino Gorge } & score & 3 & 3 & 4 & 2 & 4 & 1 & 4 & 2 & 1 & 4 & 3 & 1 & 4 & - \\
\hline & value & 30 & 30 & 20 & 20 & 20 & 5 & 20 & 30 & 10 & 20 & 30 & 5 & 20 & 260 \\
\hline
\end{tabular}


For the geosites of international and national relevance, a positive correspondence between high SV and PTU values is observed. In fact, the Fossiliferous limestones of Pietraroja geosite reaches the highest values both for SV and PTU (Tables 2 and 3), confirming its importance within the Matese National Park area. Furthermore the three geosites of national relevance (Cava Canale, Regia Piana bauxite Mines and Matese Lake polje) are characterized by PTU values among the highest ones.

Naturally, higher scientific values not necessarily correspond to higher potential touristic use values and vice versa (Figure 10). For example, the Lacustrine deposits of San Massimo geosite has obtained the lowest PTU value (195), but a SV of 165 close to the median value (170), which corresponds to the SV obtained by the Campitello Matese polje geosite (Table 2) that instead has obtained the third highest PTU value (295). Regarding the Campitello Matese polje geosite, its high values in the Accessibility, Logistics and Interpretative Potential criteria (Table 3), combined with the medium value related to the Scenery criterion, contribute to make this site stand out for its total PTU value when compared to the Cava Canale and Regia Piana bauxite Mines geosites, albeit of national relevance. Conversely, the relatively low PTU value of the Lacustrine deposits of San Massimo geosite essentially depends on the fact that this site has obtained the absolute lowest values for the Vulnerability and Observation conditions criteria, some of the lowest values obtained for the Use limitations, Association with other values and Proximity of recreational areas criteria, as well as the value zero related to the Scenery criterion.

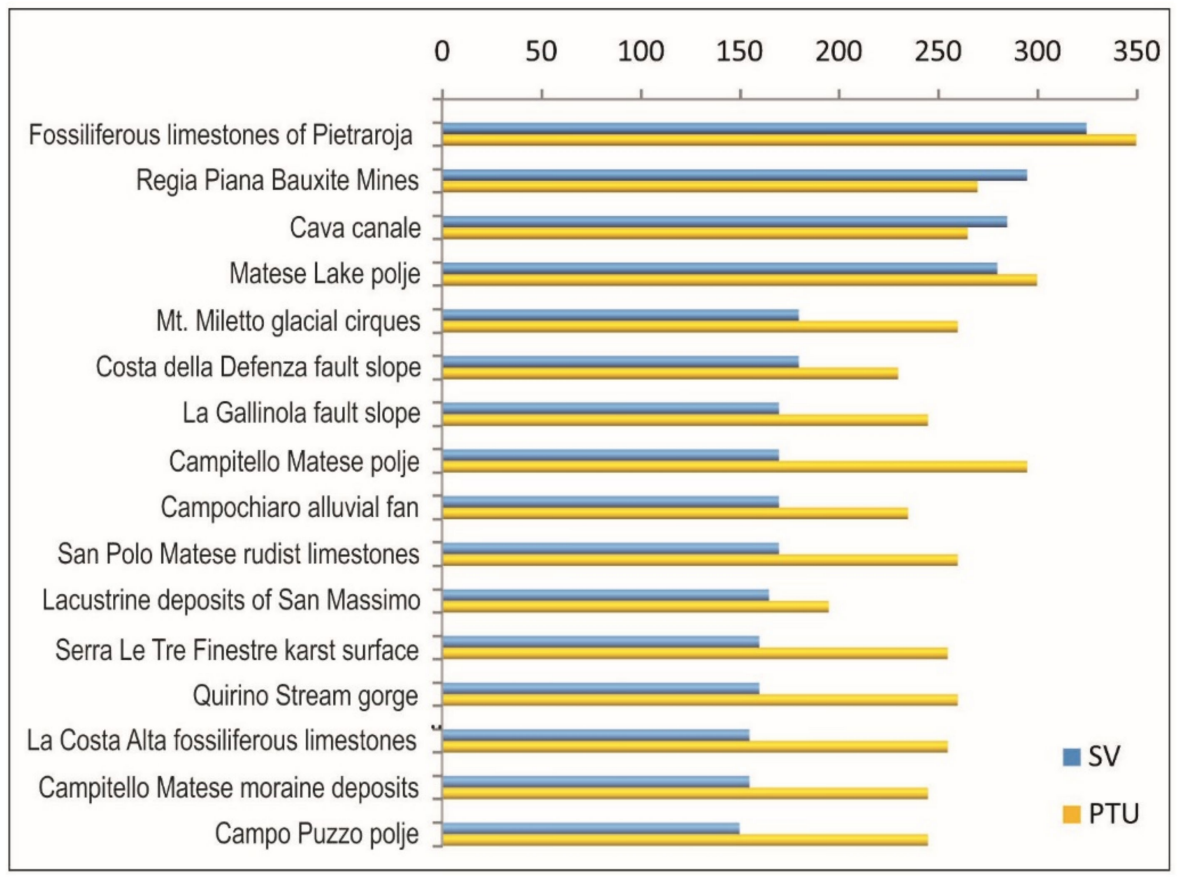

Figure 10. Comparative view of SV and PTU values assessed for the selected geosites.

\subsection{The Geoitinerary}

By overlaying the specially prepared geological map with the thematic layers containing information about the stops, the itinerary route and the geosites, we obtained the geoitinerary map shown in Figure 11. A stratigraphic column and two simplified schematic geological sections that help to visualize the distribution of stops in space and time accompany this map. A synthetic view of the stops and two examples of descriptive cards realized to illustrate single stops are shown in Figures 12-14, respectively.

Broadly, the geoitinerary crosses the Matese massif from SE to NW, with a deviation for the Lake Matese stops and the last stretch of the path that runs from NW to SE along the southern border of the Boiano Plain. The itinerary consists of 13 stops, allowing the observation of the sixteen geosites onsite and through panoramic views. It is $82 \mathrm{~km}$ long 
and has an overall difference in height of $1100 \mathrm{~m}$ (a maximum altitude of $1680 \mathrm{~m}$ is reached at stop 8, the Serra Le Tre Finestre surface, a minimum altitude of $570 \mathrm{~m}$ in correspondence of stop 12, the Campochiaro alluvial fan and Costa della Defenza slope). The geoitinerary develops mainly along the main road network allowing the visitors to move with the car from stop to stop. It also includes, however, two detours on foot, along CAI (Club Alpino Italiano) trails, to reach respectively stop 3 and stop 8 (Bauxite deposits of Regia Piana and the Serra Le tre Finestre surface, Figure 12).

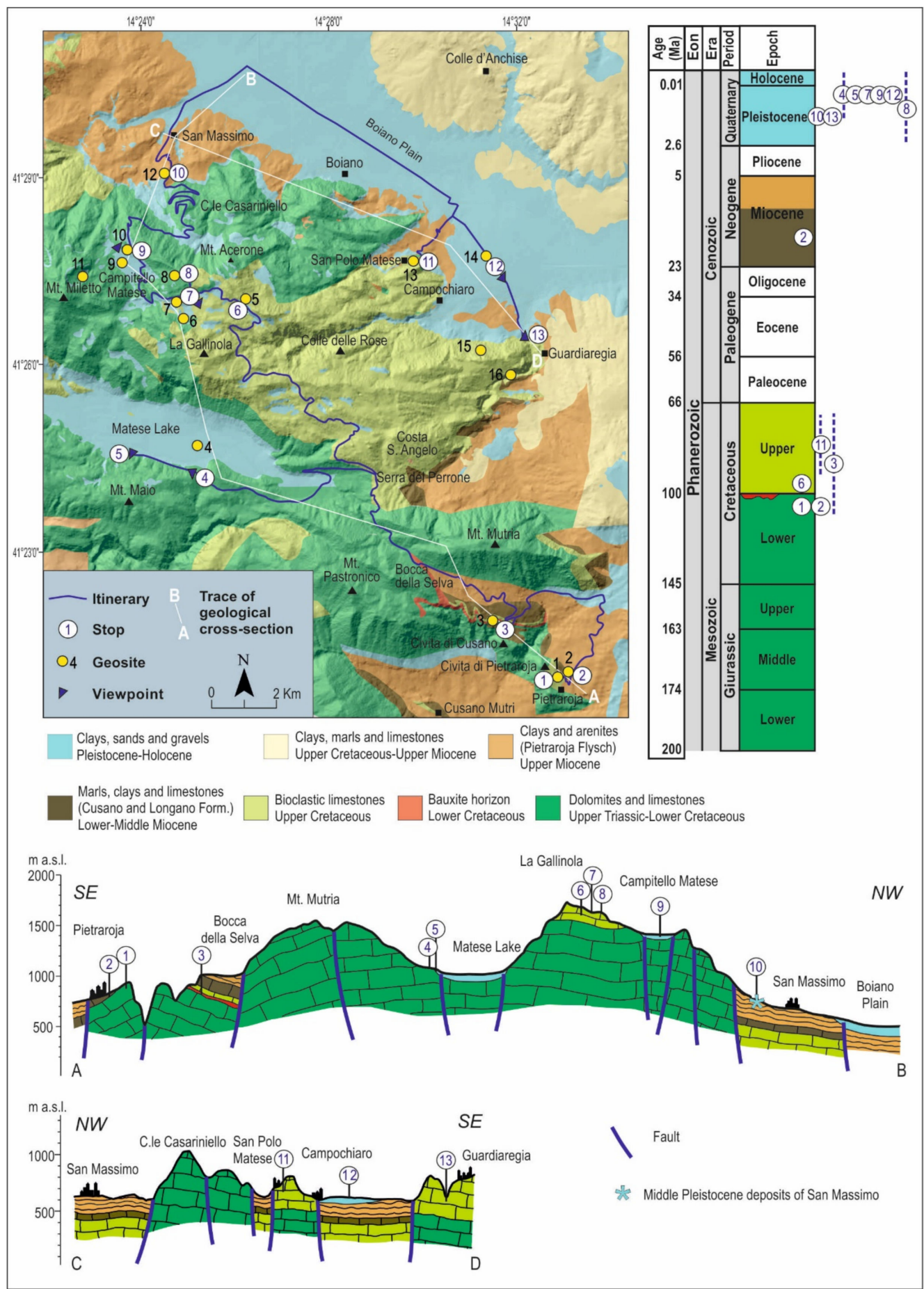

Figure 11. The geoitinerary map with the two simplified schematic geological sections and the stratigraphic column. 
It takes at least two days to complete the entire route.

Much of the itinerary crosses high mountain areas. Therefore, due to the more difficult observation conditions of geosites and the difficult accessibility due to even partial closure of some roads (such as the SP106 road connecting Serra del Perrone with Campitello Matese) during autumn and winter, related to adverse weather conditions (i.e., the presence of snow and ice), the recommended visiting season is spring/summer.

\begin{tabular}{|c|c|c|c|c|}
\hline \multicolumn{2}{|c|}{ Stop } & \multirow[t]{2}{*}{ Geosites } & \multirow[t]{2}{*}{ Main themes } & \multirow[t]{2}{*}{ Time interval } \\
\hline $\mathbf{N}$ & Name & & & \\
\hline 1 & $\begin{array}{l}\text { The Pietratoja fossiliferous } \\
\text { limestones: a Lower Cretaceous } \\
\text { tropical shallow-water } \\
\text { environment }\end{array}$ & $\begin{array}{l}\text { 1. Fossiliferous } \\
\text { limestones of } \\
\text { Pietraroja (Le Cavere) }\end{array}$ & $\begin{array}{l}\text { Paleogeography } \\
\text { Geohistory } \\
\text { Paleoclimate }\end{array}$ & Lower Cretaceous \\
\hline 2 & $\begin{array}{l}\text { The Cava Canale site: the } \\
\text { Miocene transgression in the } \\
\text { Southern Apennine chain }\end{array}$ & 2 Cava Canale & $\begin{array}{l}\text { Paleogeography } \\
\text { Geohistory }\end{array}$ & $\begin{array}{l}\text { Lower Cretaceous } \\
\text { Lower-Middle } \\
\text { Miocene }\end{array}$ \\
\hline 3 & $\begin{array}{l}\text { The Bauxite deposits of Regia } \\
\text { Piana: a tropical continental } \\
\text { phase in the Cretaceous marine } \\
\text { succession }\end{array}$ & $\begin{array}{l}3 \text { Regia Piana Bauxite } \\
\text { Mines }\end{array}$ & $\begin{array}{l}\text { Paleogeography } \\
\text { Geohistory } \\
\text { Paleoclimate } \\
\text { Tectonics } \\
\text { Karst }\end{array}$ & $\begin{array}{l}\text { Lower Cretaceous } \\
\text { Upper Cretaceous }\end{array}$ \\
\hline $4-5$ & $\begin{array}{l}\text { The Matese Lake: the } \\
\text { Pleistocene extensional } \\
\text { tectonics and the karst } \\
\text { modeling }\end{array}$ & 4 Matese Lake polje & $\begin{array}{l}\text { Tectocnics } \\
\text { Karst } \\
\text { Hydrogeology } \\
\text { Long term landscape } \\
\text { evolution }\end{array}$ & $\begin{array}{l}\text { Middle Pleistocene- } \\
\text { Holocene }\end{array}$ \\
\hline 6 & $\begin{array}{l}\text { La Costa Alta: an Upper } \\
\text { Cretaceous shelf lagoon } \\
\text { environment }\end{array}$ & $\begin{array}{l}5 \text { La Costa Alta } \\
\text { fossiliferous } \\
\text { limestones }\end{array}$ & Paleogeography & Upper Cretaceous \\
\hline \multirow[t]{2}{*}{7} & \multirow{2}{*}{$\begin{array}{l}\text { Campo Puzzo: a panoramic view } \\
\text { on active morphodynamics and } \\
\text { typical landscape features of a } \\
\text { high-mountain carbonate area }\end{array}$} & 6 Campo Puzzo Polje & \multirow{2}{*}{$\begin{array}{l}\text { Long term landscape } \\
\text { evolution } \\
\text { Karst } \\
\text { Tectonics } \\
\text { Active morphodynamics }\end{array}$} & \multirow[t]{2}{*}{$\begin{array}{l}\text { Middle Pleistocene- } \\
\text { Holocene }\end{array}$} \\
\hline & & $\begin{array}{l}7 \text { La Gallinola fault } \\
\text { slope }\end{array}$ & & \\
\hline 8 & $\begin{array}{l}\text { The Serra Le Tre Finestre } \\
\text { surface: a remnant of ancient } \\
\text { gentle and low relief erosional } \\
\text { landscapes }\end{array}$ & $\begin{array}{l}8 \text { Serra Le Tre Finestre } \\
\text { karst surface }\end{array}$ & $\begin{array}{l}\text { Karst } \\
\text { Long term landscape } \\
\text { evolution } \\
\text { Tectonics }\end{array}$ & $\begin{array}{l}\text { Lower Pleistocene- } \\
\text { Holocene }\end{array}$ \\
\hline \multirow[t]{3}{*}{9} & \multirow{3}{*}{$\begin{array}{l}\text { The Campitello Matese area: } \\
\text { the karst modeling and the } \\
\text { Pleistocene glaciations }\end{array}$} & $\begin{array}{l}9 \text { Campitello Matese } \\
\text { polje }\end{array}$ & \multirow{3}{*}{$\begin{array}{l}\text { Long term landscape } \\
\text { evolution } \\
\text { Karst } \\
\text { Hydrogeology } \\
\text { Tectonics } \\
\text { Paleoclimate } \\
\text { Active morphodynamics }\end{array}$} & \multirow[t]{3}{*}{$\begin{array}{l}\text { Middle Pleistocene- } \\
\text { Holocene }\end{array}$} \\
\hline & & $\begin{array}{l}10 \text { Campitello Matese } \\
\text { moraine deposits }\end{array}$ & & \\
\hline & & $\begin{array}{l}11 \mathrm{Mt} \text {. Miletto glacial } \\
\text { cirques }\end{array}$ & & \\
\hline 10 & $\begin{array}{l}\text { The deposits of San Massimo: } \\
\text { remnants of a } 600.000 \text { years old } \\
\text { lake }\end{array}$ & $\begin{array}{l}12 \text { Lacustrine deposits } \\
\text { of San Massimo }\end{array}$ & $\begin{array}{l}\text { Long term landscape } \\
\text { evolution } \\
\text { Paleogeography } \\
\text { Paleoclimate }\end{array}$ & Middle Pleistocene \\
\hline 11 & $\begin{array}{l}\text { The Rudists of San Polo Matese: } \\
\text { a Upper Cretaceous fossil reef }\end{array}$ & $\begin{array}{l}13 \text { San Polo Matese } \\
\text { Rudist limestones }\end{array}$ & $\begin{array}{l}\text { Paleogeography } \\
\text { Geohistory }\end{array}$ & Upper Cretaceous \\
\hline \multirow[t]{2}{*}{12} & \multirow{2}{*}{$\begin{array}{l}\text { The Campochiaro fan and Costa } \\
\text { della Defenza slope: the } \\
\text { Quaternary tectonics and } \\
\text { climate variations }\end{array}$} & $\begin{array}{l}14 \text { Campochiaro } \\
\text { alluvial fan }\end{array}$ & \multirow{2}{*}{$\begin{array}{l}\text { Long term landscape } \\
\text { evolution } \\
\text { Paleoclimate } \\
\text { Tectonics }\end{array}$} & \multirow[t]{2}{*}{$\begin{array}{l}\text { Middle Pleistocene- } \\
\text { Holocene }\end{array}$} \\
\hline & & $\begin{array}{l}15 \text { Costa della Defenza } \\
\text { fault slope }\end{array}$ & & \\
\hline 13 & $\begin{array}{l}\text { The Quirino Gorge: an evidence } \\
\text { of Quaternary tectonics and } \\
\text { stream superimposition }\end{array}$ & 16 Quirino Gorge & $\begin{array}{l}\text { Long term landscape } \\
\text { evolution } \\
\text { Tectonics }\end{array}$ & Middle Pleistocene \\
\hline
\end{tabular}

Figure 12. Summary of the stops of the itinerary, with the geosites that allow visiting, the main themes and the time interval embraced.

The two examples of descriptive cards (Figures 13 and 14) concern stops 2 and 9 (Figure 11), located respectively in the southeastern and the central northern sectors of the Matese area. The card on stop 2 is dedicated to the Miocene transgression in the Matese 
area and the related Cretaceous and Miocene paleogeography (Cava Canale site). The card on stop 9 deals with the Quaternary landscape evolution in the Campitello Matese area. These cards provide some essential information, through text, photos and figures, to illustrate to visitors the major themes on which the stops focus.

\section{The Cava Canale site:}

2

\section{the Miocene trasgression in the Southern Apennine chain}

The Miocene transgressive carbonate marine deposits of the Cusano Formation (Mi) resting on the Lower Cretaceous limestones $(\mathrm{Cr})$ are very well exposed (A).

The marine transgression took place after a long period of non-deposition or erosion (B), as evidenced by the absence in the succession of the Upper Cretaceous and Paleogene

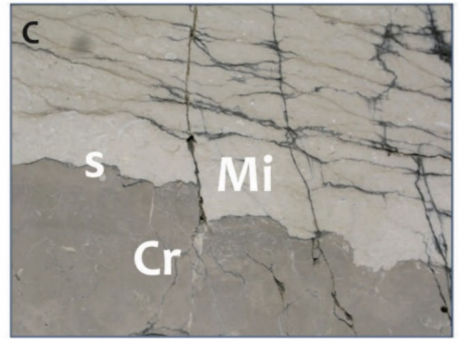

The Miocene limestones fill cavities produced by erosion in the Cretaceous bedrock.

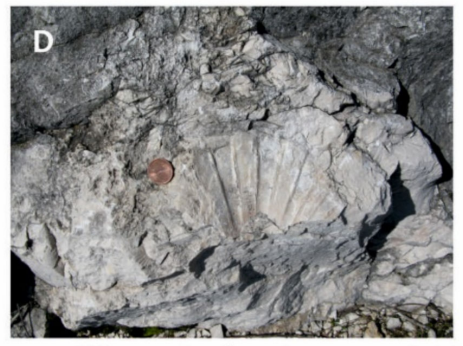

Lamellibranchs (such as pectinids and ostreids) are observable within the Miocene limestones.

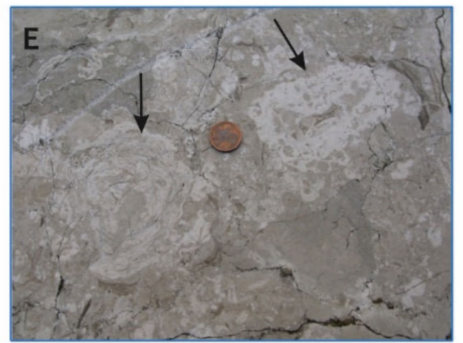

Rhodoliths, which are unattached calcareous nodules, composed of coralline red algae, are also visible.

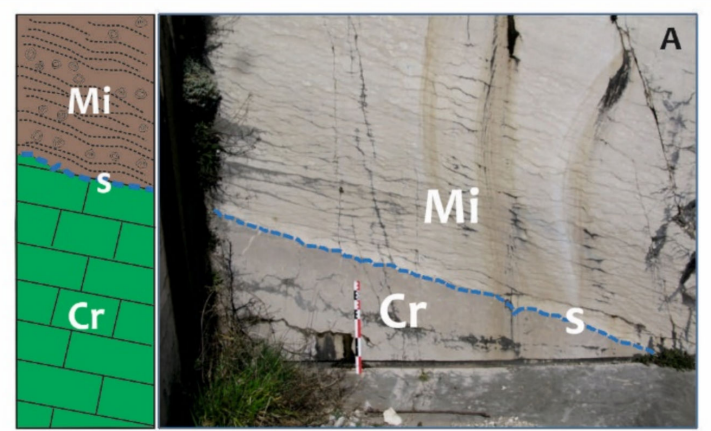

The trasgression surface $(\mathrm{s})$ is easly recognizable. Above this surface (C), the Miocene Cusano Formation is made mainly by bioclastic limestones (D, E).

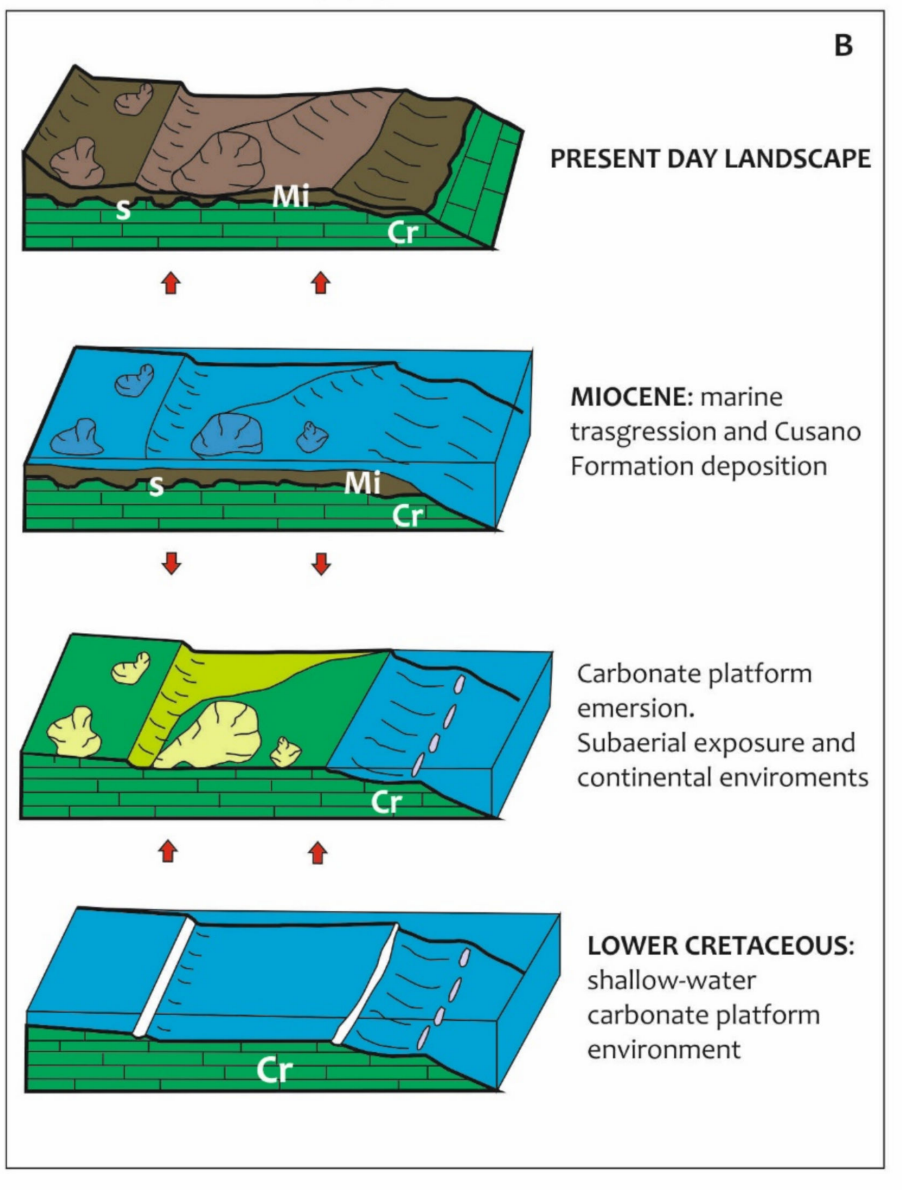

Figure 13. The descriptive card prepared for the visit of the Cava Canale site-Stop 2. 
9. The Campitello Matese area: the karst modeling and the Pleistocene glaciations

A rich assemblage of glacial, karst, fluvial and slope landforms gives evidence of the Late Quaternary evolution of this area (A). The Campitello Plain is a good example of polje: a large, flat-floored karst depression (B). It is an active polje, mainly controlled by NW-SE tectonic lineaments. On its floor, some ponors, ensuring the endorheic drainage, and the uppermost portion of its filling are easily observable (A).
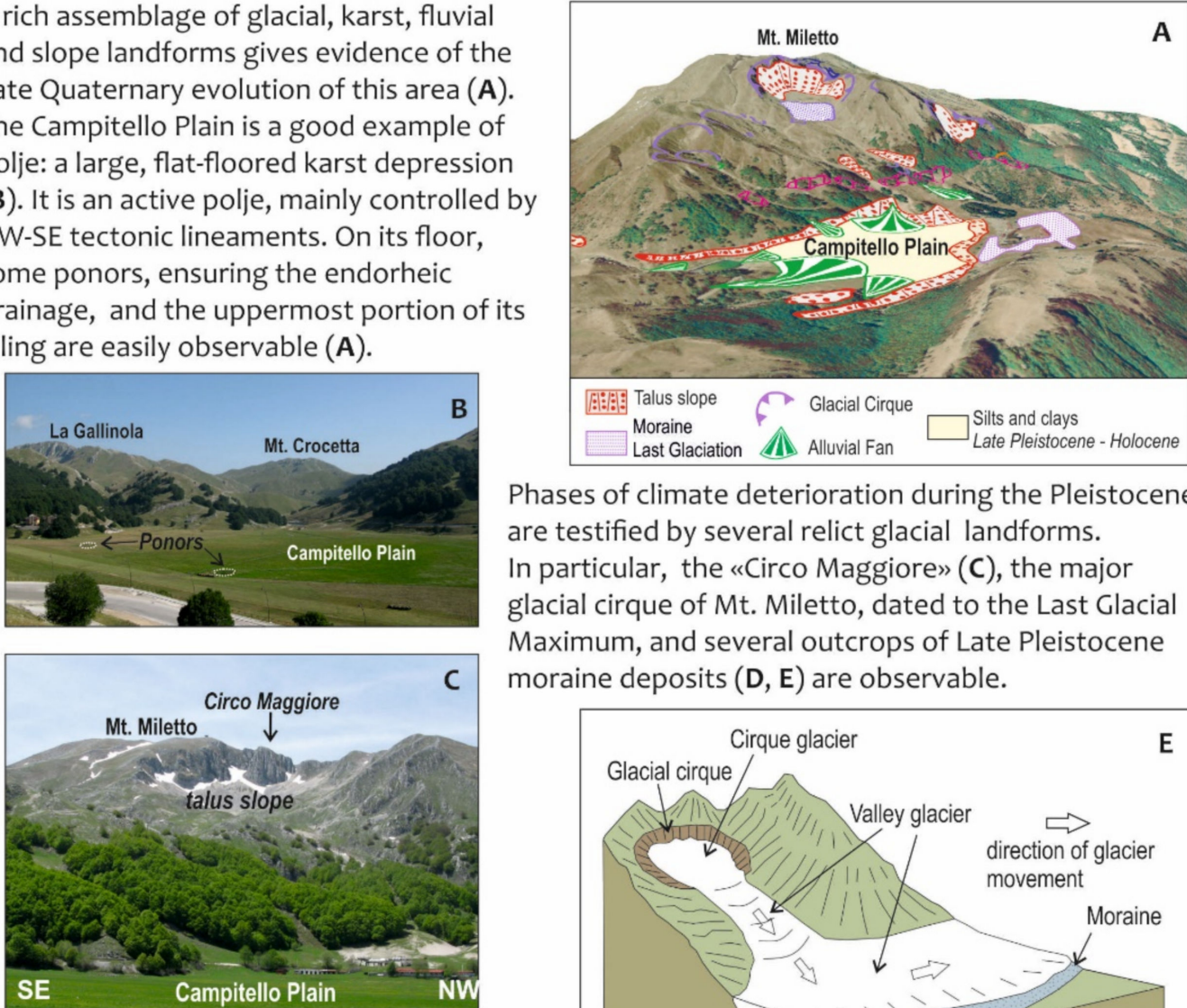

Phases of climate deterioration during the Pleistocene are testified by several relict glacial landforms. In particular, the «Circo Maggiore» (C), the major glacial cirque of Mt. Miletto, dated to the Last Glacial Maximum, and several outcrops of Late Pleistocene moraine deposits (D, E) are observable.

The Circo Maggiore shows the typical features of glacial cirques (E): the amphitheatre-like shape and the steep headwalls, partially covered by active scree slopes.

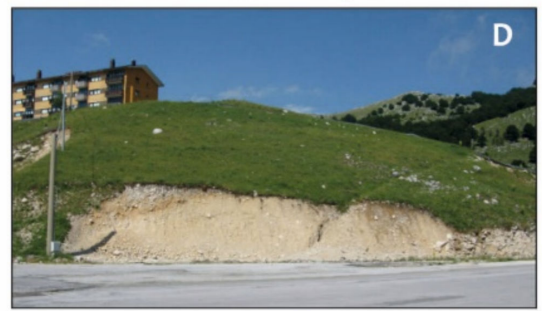

The moraine deposits typically consist of sub-angular, highly heterometric, calcareous clasts in very abundant sandy-silty matrix.

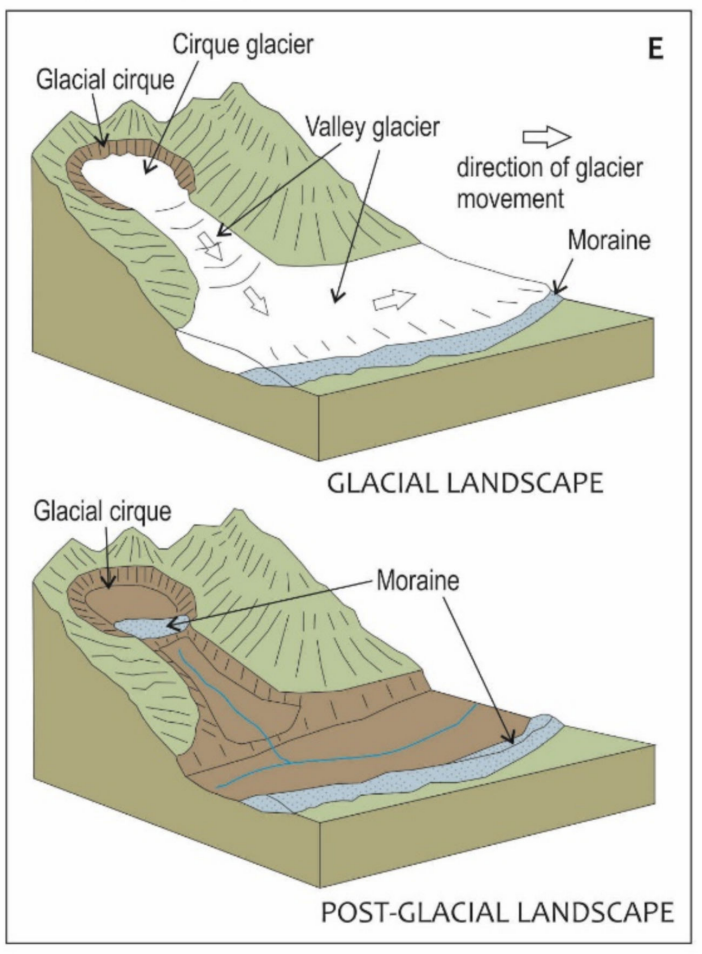

Figure 14. The descriptive card prepared for the visit of the Campitello Matese area-Stop 9.

The card of the Cava Canale stop (Figure 13) provides information on the major geological features observable in the disused quarry, which are also easily recognizable by a non-expert audience. It contains four pictures that show some of the main observations that visitors can make along the quarry walls, and a picture containing a sequence of very simplified 3D evolutive schemes. In particular, picture A, accompanied by an interpretative simplified stratigraphic column, shows the Cretaceous and Miocene limestones separated by the transgression surface. Picture $C$ shows in detail the transgression surface, highlighting its erosive nature, while pictures $\mathrm{D}$ and $\mathrm{E}$ show the fossils that are easily recognizable 
in this site. Finally, the simplified 3D evolutive schemes in picture B allow visualizing the evolution of the carbonate platform in the area, with particular reference to what can be observed on the site and the paleoenvironments in which the now outcropping rocks were originally formed.

The card of the Campitello Matese stop (Figure 14) provides information on the major landforms observable, and on the processes responsible for their formation and involved in the Quaternary landscape evolution of this area. It contains five pictures, three of which show the landforms that are easily recognizable in this area even by a non-specialist audience, and representative of the three geosites present in this area: the Campitello Matese polje (B), the Mt. Miletto glacial cirques (C) and the Campitello Matese moraine deposits (D). In particular, regarding the glacial cirques, we have chosen to focus the visitor's attention on the "Circo Maggiore" (major cirque), which is the best preserved one and easier to observe. A 3D view including the different landforms (A) gives an overview of the Campitello Matese landscape. Furthermore, two simplified 3D evolutive schemes (E) are included, showing the passage from a glaciated to a non-glaciated landscape, highlighting how the now-relict glacial landforms originally formed.

\section{Discussion and Conclusions}

The present study deals with the enhancement of the geoheritage of the Matese Mountains, one of the most suggestive and integral mountain areas of southern Italy. This mountain area largely shares the hardships and limitations that widespread characterize other mountain regions and, in general, inner areas, such as land abandonment [3], population decrease [72], marginality, limits in mobility and inaccessibility [1,6].

Bearing in mind the special characteristics and physiographic features of the Matese Mountains, along with the presence of the Matese National Park currently taking off, the proposed geoitinerary, apart the obvious geotourism purpose, can help to unite separate physiographic units and overcome existing limits connected to difficult access, scarcity of infrastructures, administrative boundaries, etc.

Many of the studies on geological itineraries (see the introduction section for references) highlight the importance of a correct selection of geosites, to choose the most suitable ones for geotourism purposes.

For the geosites included in the Molise geosite census (12 of the selected geosites), the quantitative assessment of the SV provided results on overall consistent with those obtained through the quantitative assessment method used in the Molise regional census. The latter allowed to calculate the so-called intrinsic geosite value [68] resulting from the weighted sum of Representativeness, Rarity and Scenic-aesthetic values. This consistency emphasizes the adequacy of the procedure used in this work to assess the SV of the selected geosites.

In addition, the values obtained for the SV and PTU highlight that the selected geosites not only stand out for their scientific values but are mostly characterized by high to very high PTU values as well. These qualities, together with the selected stops (Figure 11), which include both on-site visits and beautiful panoramic views, allowing the illustration of the geosites in an appealing manner by also highlighting their scenic-aesthetic qualities, represent a remarkable strength of the proposed geoitinerary. The latter also manages to tell in a simply but sufficiently exhaustive manner the main steps of the geological history and long-term landscape evolution of the Matese area, highlighting its rich geoheritage and high geodiversity.

The geoitinerary crosses the municipal territories of Pietraroja, Cusano Mutri, Piedimonte Matese, Castello del Matese, San Gregorio Matese, Bojano, Campochiaro, San Polo Matese, Guardiaregia and San Massimo. The first six of these municipalities are classified as "tourist municipalities not belonging to a specific category" [117], San Massimo is defined a "municipality with a mountain vocation", San Polo Matese, Campochiaro and Guardiaregia instead as belonging to the "non-tourism municipality" category.

Tourism is concentrated mainly in the Campitello Matese district, located in the municipality of San Massimo, which is the home of a winter and ski tourism of predom- 
inantly commuting-type [72]. Other places of tourist attraction along the itinerary are Bocca della Selva (Cusano Mutri municipality), with prevailing winter tourism (essentially cross-country skiing), the Matese Lake area with its recreational outdoor activities especially during spring and summer, the WWF Oasis Guardiaregia-Campochiaro Regional Reserve, mainly visited by ecotourists and schools, and the Le Cavere geosite and Paleo-Lab Museum of Pietraroja, which are important attraction poles for geology enthusiasts.

The proposed geoitinerary can represent an opportunity to foster geotourism in the Matese area, both by attracting new tourists and by intercepting geology enthusiasts, who intend to visit or already have visited Pietraroja, bringing them to discover other features of the rich geoheritage of the Matese massif. It also can contribute to promoting a sustainable tourism during the spring and summer seasons in the Campitello Matese area.

In addition, the itinerary can act as a connection between the territories of the Campania and Molise regions, which until now have been managed in an independent and uncoordinated way, substantially in the frameworks of the Matese Regional Park and the Italian Strategy for Inner Areas, respectively. In particular, the geoitinerary can support the development of sustainable geotourism and related associate activities within the nascent Matese National Park, helping to create a tourist offering capable of attracting visitors driven by an interest in geology and in other natural or cultural resources.

Future developments of our study will be aimed at linking the geoitinerary with the visit of other sites of natural/cultural interest, and at creating a network with other trails such as the geological trails already designed for the Molise side [51], so as to encourage tourists to stay for several days and favor overnight stays. Finally, initiatives aimed at exploiting the proposed geoitinerary (for instance, the realization of illustrative panels, brochures, and illustrative materials suitable for mobile technologies), in collaboration with public administrations, private tourism managers and/or local stakeholders, are strongly hoped for and will be a further focus of our future activities.

Author Contributions: Conceptualization F.F. and C.M.R.; methodology, F.F., C.M.R., V.A. and M.C.; formal analysis, F.F. and C.M.R.; investigation, F.F., V.A. and M.C.; writing-original draft preparation, F.F. and C.M.R.; writing-review and editing, F.F. and C.M.R.; supervision, C.M.R. All authors have read and agreed to the published version of the manuscript.

Funding: This research received no external funding.

Institutional Review Board Statement: Not applicable.

Informed Consent Statement: Not applicable.

Data Availability Statement: The data presented in this study are available in the article itself, in the references cited and from the authors, upon request.

Acknowledgments: The authors wish to thank the anonymous reviewers whose suggestions contributed to improving the manuscript.

Conflicts of Interest: The authors declare no conflict of interest.

\section{References}

1. Battaglia, M.; Annesi, N.; Pierantoni, I.; Sargolini, M. Future perspectives of sustainable development: An innovative planning approach to inner areas. Experience of an Italian alpine region. Futures 2019, 114, 102468. [CrossRef]

2. Vendemmia, B.; Pucci, P.; Beria, P. An institutional periphery in discussion. Rethinking the inner areas in Italy. Appl. Geogr. 2021, 135, 102537. [CrossRef]

3. Varga, D. Are agrarian areas in Mediterranean mountain regions becoming extinct? A methodological approach to their conservation. Forests 2020, 11, 1116. [CrossRef]

4. Regato, P.; Salman, R. Mediterranean Mountains in a Changing World: Guidelines for Developing Action Plans; IUCN Centre for Mediterranean Cooperation: Malaga, Spain, 2008; p. 88.

5. Basile, G.; Cavallo, A. Rural identity, authenticity, and sustainability in Italian inner areas. Sustainability 2020, 12, 1272. [CrossRef]

6. Nepal, S.K.; Chipeniuk, R. Mountain tourism: Toward a conceptualframework. Tour. Geogr. 2005, 7, 313-333. [CrossRef]

7. Duglio, S.; Bonadonna, A.; Letey, M.; Peira, G.; Zavattaro, L.; Lombardi, G. Tourism development in inner mountain areas-The local stakeholders' point of view through a mixed method approach. Sustainability 2019, 11, 5997. [CrossRef] 
8. Nistoreanu, P.; Dorobanţu, M.R.; Tुuclea, C.E. The trilateral relationship ecotourism—Sustainable tourism—Slow travel among nature in the line with authentic tourism lovers. J. Tour. Stud. Res. Tour. 2011, 11, 35-38.

9. Dowling, R.K. Global Geotourism-An emerging form of sustainable tourism. Czech J. Tour. 2013, 2, 59-79. [CrossRef]

10. Hose, T.A.; Vasiljević, D.A. Defining the nature and purpose of modern geotourism with particular reference to the United Kingdom and South-East Europe. Geoheritage 2012, 4, 25-43. [CrossRef]

11. Ólafsdóttir, R.; Tverijonaite, E. Geotourism: A systematic literature review. Geosciences 2018, 8, 234. [CrossRef]

12. Dowling, R.K.; Newsome, D. Geotourism: Definition, characteristics and international perspectives. In Handbook of Geotourism; Dowling, R., Newsome, D., Eds.; Edward Elgar Publishing: Cheltenham, UK, 2018; pp. 1-22.

13. Widawski, K.; Jary, Z.; Oleśniewicz, P.; Owczarek, P.; Markiewicz-Patkowska, J.; Zaręba, A. Attractiveness of protected areas for geotourism purposes from the perspective of visitors: The example of Babiogórski National Park (Poland). Open Geosci. 2018, 10, 358-366. [CrossRef]

14. Tomić, N.; Marković, S.B.; Antić, A.; Tešić, D. Exploring the potential for geotourism development in the Danube Region Serbia Int. J. Geoherit. Parks 2020, 8, 123-139. [CrossRef]

15. Ateş, H.; Ateş, Y. Geotourism and rural tourism synergy for sustainable development—Marçik Valley Case-Tunceli, Turkey. Geoheritage 2019, 11, 207-215. [CrossRef]

16. Hamoud, A.; El Hadi, H.; Tahiri, A.; Chakiri, S.; Mehdioui, S.; Baghdad, B.; El Maidani, A.; Bejjaji, Z.; Aoufad, M. Mauritanian geological resources: A lever for sustainableregional development via geotourism. Int. J. Geoherit. Parks 2021, 9, 415-429. [CrossRef]

17. Farsani, N.; Coelho, C.; Costa, C. Geotourism and geoparks as novel strategies for socio-economic development in rural areas. Int J. Tour. Res. 2011, 13, 68-81. [CrossRef]

18. Farsani, N.; Coelho, C.; Costa, C. Rural geotourism: A new tourism product. Acta Geoturistica 2013, 4, 1-10.

19. Härtling, J.W.; Meier, I. Economic effects of geotourism in geopark TERRA. vita, Northern Germany. George Wright Forum 2010, 27, 29-39.

20. Lee, Y.; Jayakumar, R. Economic impact of UNESCO global geoparks on local communities in Asia: Comparative analysis of three UNESCO global geoparks in Asia. Int. J. Geoherit. Parks 2021, 9, 189-198. [CrossRef]

21. Telbisz, T.; Gruber, P.; Mari, L.; Kőszegi, M.; Bottlik, Z.; Standovár, T. Geological heritage, geotourism and local development in Aggtelek National Park (NE Hungary). Geoheritage 2020, 12, 5. [CrossRef]

22. Dóniz-Páez, J.; Hernández, P.A.; Pérez, N.M.; Hernández, W.; Márquez, A. TFgeotourism: A Project to quantify, highlight, and promote the volcanic geoheritage and geotourism in Tenerife (Canary Islands, Spain). In Updates in Volcanology. Transdisciplinary Nature of Volcano Science; Németh, K., Ed.; IntechOpen Book Series; IntechOpen: London, UK, 2021. [CrossRef]

23. Drinia, H.; Tsipra, T.; Panagiaris, G.; Patsoules, M.; Papantoniou, C.; Magganas, A. Geological Heritage of Syros Island, Cyclades Complex, Greece: An Assessment and Geotourism Perspectives. Geosciences 2021, 11, 138. [CrossRef]

24. Zafeiropoulos, G.; Drinia, H.; Antonarakou, A.; Zouros, N. From geoheritage to geoeducation, geoethics and geotourism: A critical evaluation of the Greek Region. Geosciences 2021, 11, 381. [CrossRef]

25. Sadry, B.N. The Geotourism Industry in the 21st Century: The Origin, Principles, and Futuristic Approach, 1st ed.; Apple Academic Press: Burlington, ON, Canada, 2020; p. 596.

26. Dowling, R.K.; Newsome, D. Setting an agenda for geotourism. In Geotourism. The Tourism of Geology and Landscape; Newsome, D., Dowling, R.K., Eds.; Goodfellow Publishers: Oxford, UK, 2010; pp. 1-12.

27. Dowling, R.K.; Newsome, D. Global Geotourism Perspectives; Goodfellow Publishers: Oxford, UK, 2010.

28. Dowling, R.K.; Newsome, D. Geotourism Destinations-Visitor Impacts and Site Management Considerations. Czech J. Tour. 2017, 6, 111-129. [CrossRef]

29. Gordon, J.E. Geoheritage, geotourism and the cultural landscape: Enhancing the visitor experience and promoting geoconservation. Geosciences 2018, 8, 136. [CrossRef]

30. Magagna, A.; Ferrero, E.; Giardino, M.; Lozar, F.; Perotti, L. A Selection of Geological Tours for Promoting the Italian Geological Heritage in the Secondary Schools. Geoheritage 2013, 5, 265-273. [CrossRef]

31. Marvinney, R.G.; Anderson, W.A.; Barron, H.F.; Hernández, R. The International Appalachian Trail: The ancient Appalachians as ambassador of the geosciences to modern societies. In Proceedings of the CAG-MAC/Joint Annual Meeting, Geological Association of Canada \& Mineralogical Association of Canada, Fredericton, NB, Canada, 21-23 May 2014.

32. Pica, A.; Fredi, P.; Del Monte, M. The ernici mountains Geohritage (Central Apennines, Italy): Assessment of the Geosites for Geotourism development. Geo J. Tour. Geosites 2014, 2, 193-206.

33. Bertok, C.; d'Atri, A.; Martire, L.; Barale, L.; Piana, F.; Vigna, B. A trip through deep time in the rock succession of the Marguareis Area (Ligurian Alps, South Western Piemonte). Geoheritage 2015, 7, 5-12. [CrossRef]

34. Balestro, G.; Cassulo, R.; Festa, A.; Fioraso, G.; Giardino, M.; Nicolò, G.; Perotti, L. 3D geological visualizations of geoheritage information in the Monviso Massif (Western Alps). Rend. Online Soc. Geol. Ital. 2016, 39, 81-84. [CrossRef]

35. Bentivenga, M.; Palladino, G.; Prosser, G.; Guglielmi, P.; Geremia, F.; Laviano, A. A geological itinerary through the Southern Apennine thrust belt (Basilicata-southern Italy). Geoheritage 2017, 9, 1-17. [CrossRef]

36. Martínez-Graña, A.M.; Serrano, L.; González-Delgado, J.A.; Dabrio, C.J.; Legoinha, P. Sustainable geotourism using digital technologies along a rural georoutein Monsagro (Salamanca, Spain). Int. J. Digit. Earth 2017, 10, 121-138. [CrossRef] 
37. Migoń, P.; Duszyński, F.; Jancewicz, K.; Różycka, M. From plateau to plain-Using space-for-time substitution in geoheritage interpretation, Elbsandsteingebirge, Germany. Geoheritage 2019, 11, 839-853. [CrossRef]

38. Bucci, F.; Tavarnelli, E.; Novellino, R.; Palladino, G.; Guglielmi, P.; Laurita, S.; Prosser, G.; Bentivenga, M. The history of the Southern Apennines of Italy preserved in the geosites along a geological itinerary in the High Agri Valley. Geoheritage 2019, 11, 1489-1508. [CrossRef]

39. Filocamo, F.; Di Paola, G.; Mastrobuono, L.; Rosskopf, C.M. MoGeo, a mobile application to promote geotourism in Molise region (Southern Italy). Resources 2020, 9, 31. [CrossRef]

40. Freire-Lista, D.M.; Becerra Becerra, J.E.; Simões de Abre, M. The historical quarry of pena (Vila Real, north of Portugal): Associated cultural heritage and reuse as a geotourism resource. Resour. Policy 2022, 75, 102528. [CrossRef]

41. Miccadei, E.; Piacentini, T.; Esposito, G. Geomorphosites and Geotourism in the Parks of the Abruzzo Region (Central Italy). Geoheritage 2011, 3, 233-251. [CrossRef]

42. Santangelo, N.; Romano, P.; De Santo, A.V. Geo-itineraries in the Cilento Vallo di Diano Geopark: A Tool for Tourism Development in Southern Italy. Geoheritage 2014, 7, 319-335. [CrossRef]

43. Aoulad-Sidi-Mhend, A.; Maaté, A.; Amri, I.; Hlila, R.; Chakiri, S.; Maaté, S.; Martín-Martín, M. The geological heritage of the Talassemtane National Park and the Ghomara coast Natural Area (NW of Morocco). Geoheritage 2019, 11, 1005-1025. [CrossRef]

44. Pazari, F.; Dollma, M. Geotourism potential of ZALL GJOÇAJ national park and the area nearby. Int. J. Geoherit. Parks 2019, 7, 103-110. [CrossRef]

45. Petrosino, P.; Iavarone, R.; Alberico, I. Enhancing social resilience through fruition of geological heritage in the Vesuvio National Park. Geoheritage 2019, 11, 2005-2024. [CrossRef]

46. Beltrán-Yanes, E.; Dóniz-Páez, J.; Esquivel-Sigut, I. Chinyero Volcanic Landscape Trail (Canary Islands, Spain): A geotourism proposal to identify natural and cultural heritage in volcanic areas. Geosciences 2020, 10, 453. [CrossRef]

47. Santangelo, N.; Amato, V.; Ascione, A.; Ermolli, E.R.; Valente, E. Geotourism as a tool for learning: A geoitinerary in the Cilento, Vallo di Diano and Alburni Geopark (Southern Italy). Resources 2020, 9, 67. [CrossRef]

48. Marino Alfonso, J.L.; Poblete Piedrabuena, M.Á.; Beato Bergua, S.; Herrera Arenas, D. Geotourism itineraries and augmented reality in the geomorphosites of the Arribes del Duero Natural Park (Zamora Sector, Spain). Geoheritage 2021, 13, 16. [CrossRef]

49. Rais, J.; Barakat, A.; Louz, E.; Ait Barka, A. Geological heritage in the M'Goun geopark: A proposal of geo-itineraries around the Bine El Ouidane dam (Central High Atlas, Morocco). Int. J. Geoherit. Parks 2021, 9, 242-263. [CrossRef]

50. Rosskopf, C.M.; Cesarano, M.; Filocamo, F.; Aucelli, P.P.C.; Brancaccio, L.; Pappone, G. Itinerario 5 Molise. In Guide Geologiche Regionali. Campania e Molise; Calcaterra, D., D’Argenio, B., Pappone, G., Petrosino, P., Eds.; Litografia Alcione: Lavis, Italy, 2016; pp. 117-138.

51. Filocamo, F.; Rosskopf, C.M. The geological heritage for the promotion and enhancement of a territory. A proposal of geological itineraries in the Matese area (Molise, Southern Italy). Rend. Online Soc. Geol. Ital. 2019, 49, 142-148. [CrossRef]

52. Ruggiero, E.; Amore, O.; Anzalone, E.; Barbera, C.; Cavallo, S.; Conte, M.; Fiano, V.; Massa, B.; Raia, P.; Sgrosso, I.; et al. I Geositi del Parco Regionale del Matese: Itinerario da Pesco Rosito a Cerreto Sannita. Geologiadell'Ambiente 2003, 2003, $181-192$.

53. D'Argenio, B.; Ferranti, L.; Carannante, G.; Simone, L. Itinerario 6 Monti del Matese. In Guide Geologiche Regionali. Campania e Molise; Calcaterra, D., D’Argenio, B., Pappone, G., Petrosino, P., Eds.; Litografia Alcione: Lavis, Italy, 2016; pp. $139-151$.

54. Bartiromo, A. Plant remains from the Lower Cretaceous Fossil-Lagerstatte of Pietraroja, Benevento, southern Italy. Cretac. Res. 2013, 46, 65-79. [CrossRef]

55. Breislak, S. Topografia Fisica della Campania; Nella Stamperia di Antonio Brazzini: Firenze, Italy, 1798.

56. Mostardini, F.; Merlini, S. Appennino centro-meridionale. Sezioni geologiche e porposta di modello strutturale. Mem. Soc. Geol. Ital. 1986, 35, 177-202.

57. Patacca, E.; Scandone, P.; Bellatalla, M.; Perilli, N.; Santini, U. La zona di giunzione tra l'arco appenninico settentrionale e l'arco appenninico meridionale nell'Abruzzo e nel Molise. In Studi Preliminari All'acquisizione Dati del Profilo CROP 11 Civitavecchia-Vasto; Tozzi, M., Cavinato, G.P., Parotto, M., Eds.; Special Issue 1991-2; Studi Geologici Camerti: Camerino, Italy, $1992 ;$ pp. $417-441$.

58. Hippolyte, J.C.; Angelier, J.; Barrier, E. Compressional and extensional tectonics in an arc system: Example from the Southern Apennines. J. Struct. Geol. 1995, 17, 1725-1740. [CrossRef]

59. Robustini, P.; Corrado, S.; Di Bucci, D.; Calabrò, R.A.; Tornaghi, M. Comparison between contractional deformation styles in the Matese Mountains: Implications for shortening rates in the Apennines. Boll. Soc. Geol. Ital. 2003, 122, $295-306$.

60. Vitale, S.; Ciarcia, S. Tectono-stratigraphic setting of the Campania region (Southern Italy). J. Maps 2018, 14, 9-21. [CrossRef]

61. Carannante, G.; Signore, M.; Vigorito, M. Vertebrate-rich Plattenkalk of Pietraroia (Lower Cretaceous, Southern Apennines, Italy): A new model. Facies 2006, 52, 555-577. [CrossRef]

62. Bassi, D.; Carannante, G.; Checconi, A.; Simone, L.; Vigorito, M. Sedimentological and palaeoecological integrated analysis of a Miocene channelized carbonate margin, Matese Mountains, Southern Apennines, Italy. Sediment. Geol. 2010, 230, 105-122. [CrossRef]

63. Boncio, P.; Dichiarante, A.M.; Auciello, E.; Saroli, M.; Stoppa, F. Normal faulting along the western side of the Matese Mountains: Implications for active tectonics in the Central Apennines (Italy). J. Struct. Geol. 2016, 82, 16-36. [CrossRef]

64. Galli, P.; Giaccio, B.; Messina, P.; Peronace, E.; Amato, V.; Naso, G.; Nomade, S.; Pereira, A.; Piscitelli, S.; Bellanova, J.; et al. Middle to Late Pleistocene activity of the northern Matese fault system (southern Apennines, Italy). Tectonophysics 2017, 699, 61-81. [CrossRef] 
65. Valente, E.; Buscher, J.T.; Jourdan, F.; Petrosino, P.; Reddy, S.M.; Tavani, S.; Corradetti, A.; Ascione, A. Constraining mountain front tectonic activity in extensional setting from geomorphology and Quaternary stratigraphy: A case study from the Matese ridge, southern Apennines. Quat. Sci. Rev. 2019, 219, 47-67. [CrossRef]

66. Esposito, A.; Galvani, A.; Sepe, V.; Atzori, S.; Brandi, G.; Cubellis, E.; De Martino, P.; Dolce, M.; Massucci, A.; Obrizzo, F.; et al. Concurrent deformation processes in the Matese massif area (Central-Southern Apennines, Italy). Tectonophysics 2020, 774, 228234. [CrossRef]

67. Amato, V.; Aucelli, P.P.C.; Cesarano, M.; Rosskopf, C.M.; Cifelli, F.; Mattei, M. A 900 m-deep borehole from Boiano intermontane basin (Southern Apennines, Italy): Age constraints and palaeoenvironmental features of the Quaternary infilling. Geol. J. 2020, 56, 2148-2166. [CrossRef]

68. Filocamo, F.; Rosskopf, C.M.; Amato, V. A contribution to the understanding of the Apennine landscapes: The potential role of Molise Geosites. Geoheritage 2019, 11, 1667-1688. [CrossRef]

69. Giraudi, C. Datazione diretta e correlazione di depositi glaciali con l'uso di tephra e loess: Il caso del Matese (Campania-Molise). Quaternario 1999, 12, 11-16.

70. Aucelli, P.P.C.; Cesarano, M.; Di Paola, G.; Filocamo, F.; Rosskopf, C.M. Geomorphological map of the central sector of the Matese Mountains (Southern Italy): An example of complex landscape evolution in a Mediterranean mountain environment. J. Maps 2013, 9, 604-616. [CrossRef]

71. ISPRA 2028. Analisi delle Valenze Ambientali Dell'area di Interesse per L'istituzione del Parco Nazionale del Matese. Available online: https:/ / www.naturacampania.it/Presentazione\%20Matese-ISPRA_dic_18.pdf (accessed on 24 November 2021).

72. Forleo, M.B.; Giannelli, A.; Giaccio, V.; Palmieri, N.; Mastronardi, L. Geosites and parks for the sustainable development of inner areas: The Matese Mountain (Italy). Geo J. Tour. Geosites 2017, 20, 231-242.

73. Rosskopf, C.M.; Di Paola, G.; Filocamo, F. Carta di Sintesi dei Geositi Molisani 2014; Regione Molise: Campobasso, Italy, 2014.

74. I Geositi del Molise. Available online: http://www3.regione.molise.it/flex/cm/pages/ServeBLOB.php/L/IT/IDPagina/382 (accessed on 8 January 2022).

75. ISPRA. The Italian Geosites Inventory. Available online: http://sgi.isprambiente.it/GeositiWeb/ (accessed on 23 December 2021).

76. Carta dei Geositi. Available online: http://www.difesa.suolo.regione.campania.it/content/category/6/46/71/ (accessed on 23 December 2021).

77. Piano Territoriale Regionale. Geopotale Regione Campania. Available online: https:/ /sit2.regione.campania.it/content/pianoterritoriale-regionale (accessed on 23 December 2021).

78. Taddei, A.; Cotugno, R.; Fraissinet, M.; Massa, B.; Ruggiero, E. The 18 Geosites of Matese Regional Park (Campania, Southern Italy) proposed for inclusion in the APAT Italian Geosites database. In Proceedings of the 32nd International Geological Congress, Florence, Italy, 20-28 August 2004; Abstracts Part 1, pp. 240-241.

79. Ruggiero, E.; Taddei, A. Parco Naturale Regionale del Matese. In Patrimonio Geologico e Geodiversità. Esperienze ed Attività dal Servizio Geologico d'Italia all'APAT; D'Andrea, M., Lisi, A., Mezzetti, T., Eds.; Rapporti 51/2005; APAT: Rome, Italy, 2006; pp. 177-186.

80. Coratza, P.; Giusti, C. Methodological proposal for the assessment of the scientific quality of geomorphosites. Quaternario 2005, 18, 307-313.

81. Reynard, E.; Fontana, G.; Kozlik, L.; Scapozza, C. A method for assessing scientific and additional values of geomorphosites. Geogr. Helv. 2007, 62, 148-158. [CrossRef]

82. Pereira, P.; Pereira, D.I. Methodological guidelines for geomorphosite assessment. Geomorphol. Relief Process. Environ. 2010, 2, 215-222. [CrossRef]

83. Bruschi, V.M.; Cendrero, A.; Albertos, J.A.C. A statistical approach to the validation and optimisation of geoheritage assessment procedures. Geoheritage 2011, 3, 131-149. [CrossRef]

84. Coratza, P.; Bruschi, V.; Piacentini, D.; Saliba, D.; Soldati, M. Recognition and assessment of Geomorphosites in Malta at the Il-Majjistral Natural and History Park. Geoheritage 2011, 3, 175-185. [CrossRef]

85. Fassoulas, C.; Mouriki, D.; Dimitriou-Nikolakis, P.; Iliopoulos, G. Quantitative assessment of geotopes as an effective tool for geoheritage management. Geoheritage 2012, 4, 177-193. [CrossRef]

86. Brilha, J. Inventory and quantitative assessment of geosites and geodiversity sites: A review. Geoheritage 2016, 8, 119-134. [CrossRef]

87. Brilha, J. Geoheritage: Inventories and evaluation. In Geoheritage: Assessment, Protection and Management; Reynard, E., Brilha, J., Eds.; Elsevier: Amsterdam, The Netherlands, 2018; pp. 69-86.

88. Cappadonia, C.; Coratza, P.; Agnesi, V.; Soldati, M. Malta and Sicily joined by geoheritage enhancement and geotourism within the framework of land management and development. Geosciences 2018, 8, 253. [CrossRef]

89. Albani, R.A.; Mansur, K.L.; Carvalho, I.d.S.; Santos, W.F.S.D. Quantitative evaluation of the geosites and geodiversity sites of João Dourado Municipality (Bahia-Brazil). Geoheritage 2020, 12, 46. [CrossRef]

90. ISPRA. Scheda per L'inentario dei Geositi Italiani. Available online: http://sgi.isprambiente.it/geositiweb/public/scheda_ geositi.pdf (accessed on 23 December 2021)

91. Mucivuna, V.C.; Garcia, M.G.M.; Reynard, E. Comparing quantitative methods on the evaluation of scientific value in geosites: Analysis from the Itatiaia National Park, Brazil. Geomorphology 2022, 396, 107988. [CrossRef] 
92. Mucivuna, V.C.; Garcia, M.G.M. Geomorphosites assessment methods: Comparative analysis and typology. Geoheritage 2019, 11, 1799-1815. [CrossRef]

93. ISTAT. Istituto Nazionale di Statistica. Available online: https://www.istat.it/ (accessed on 15 November 2021).

94. Prosser, C.D.; Burek, C.V.; Evans, D.H.; Gordon, J.E.; Kirkbride, V.B.; Rennie, A.F.; Walmsley, C.A. Conserving geodiversity sites in a changing climate: Management challenges and responses. Geoheritage 2010, 2, 123-136. [CrossRef]

95. Zorina, S.O.; Silantiev, V.V. Geosites, Classification of. In Encyclopedia of Mineral and Energy Policy; Tiess, G., Majumder, T., Cameron, P., Eds.; Springer: Berlin/Heidelberg, Germany, 2014. [CrossRef]

96. Rook, L.; Pandolfi, L. Paleodays 2019. La Società Paleontologica Italiana a Benevento e Pietraroja. Parte 2: Guida all'e Scursione della XIX Riunione Annuale SPI (Società Paleontologica Italiana); Ente GeoPaleontologico di Pietraroja (Benevento): Pietraroja, Italy, 2019; p. 24.

97. Carannante, G.; Puglies, A.; Ruberti, D.; Simone, L.; Vigliotti, M.; Vigorito, M. Evoluzione cretacica di un settore della piattaforma apula da dati di sottosuolo e di affioramento (Appennino campano-molisano). Ital. J. Geosci. 2009, 128, 3-31.

98. Parona, C.F. Le Rudiste e le Camacee di S. Polo Matese raccolte da Francesco Bassani. Mem. Regia Accad. Sci. Torino 1901, 50, 197-214

99. Catenacci, E.; De Castro, P.; Sgrosso, I. Complessi guida del Mesozoico calcareo-dolomitico nella zona orientale del Massiccio del Matese. Mem. Soc. Geol. Ital. 1962, 4, 837-856.

100. Selli, R. Sulla trasgressione del Miocene nell'Italia meridionale. Giorn. Geol. 1957, 26, 1-54.

101. Dal Sasso, C.; Signore, M. Exceptional soft-tissue preservation in a theropod dinosaur from Italy. Nature 1998, 392, 383-387. [CrossRef]

102. Barbera, C.; Simone, L.; Carannante, G. Depositi circalittorali di piattaforma aperta nel Miocene Campano. Analisi sedimentologica e paleoecologica. Boll. Soc. Geol. Ital. 1978, 97, 821-834.

103. Carannante, G.; Simone, L. Rhodolith facies in the central-southern Apennines Mountains, Italy. In Models for Carbonate Stratigraphy from Miocene Reef Complexes of Mediterranean Regions; Franseen, E.K., Esteban, M., Rouchy, J.M., Eds.; SEPM Concepts in Sedimentology and Paleontology; SEPM: Tulsa, OK, USA, 1966; Volume 5, pp. 261-275.

104. D'Argenio, B.; Mindszenty, A. Bauxites and related paleokarst: Tectonic and climatic event markers at regional unconformities. Eclogae Geol. Helv. 1995, 88, 453-499.

105. Del Prete, S.; Mele, R.; Allocca, F.; Bocchino, B. Le miniere di bauxite di Cusano Mutri. (Monti del Matese -Campania). Opera Ipogea 2002, 1, 3-34.

106. Pappone, G.; Aucelli, P.P.C.; Cesarano, M.; Putignano, M.L.; Ruberti, D. Note Illustrative del Foglio 405 Campobasso della Carta Geologica d'Italia alla Scala 1: 50.000; ISPRA: Roma, Italy, 2013.

107. Fiorillo, F.; Pagnozzi, M. Recharge processes of Matese karst massif (southern Italy). Environ. Earth Sci. 2015, 74, 7557-7570. [CrossRef]

108. Ruggero, P. Risultati di alcune indagini sul regime idrologico del Massiccio del Matese. Ann. Lav. Pubblici 1926, 64, $381-401$.

109. Civita, M. Valutazione analitica delle riserve in acque sotterranee alimentanti alcune tra le principali sorgenti del massiccio del Matese (Italia meridionale). Mem. Soc. Nat. Napoli 1969, 78, 133-163.

110. Giraudi, C.; Zanchetta, G.; Sulpizio, R. A Late-Pleistocene phase of Saharan dust deposition in the high Apennine mountains (Italy). Alp. Mediterr. Quat. 2013, 26, 110-122.

111. Palmentola, G.; Acquafredda, P. Gli effetti dei ghiacciai quaternari sulla montagna del Matese, al confine molisano-campano. Geogr. Fis. Din. Quat. 1983, 6, 117-130.

112. Brancaccio, L.; Cinque, A.; Orsi, G.; Pece, R.; Rolandi, G.; Sgrosso, I. Lembi residui di sedimenti lacustri pleistocenici sospesi sul versante settentrionale del Matese, presso S. Massimo. Boll. Soc. Nat. Napoli 1979, 88, 275-286.

113. Di Bucci, D.; Naso, G.; Corrado, S.; Villa, I. Growth, interaction and sismogenic potential of coupled active normal faults (Isernia Basin, Central-Southern Italy). Terra Nova 2005, 17, 44-55. [CrossRef]

114. Ferrarini, F.; Boncio, P.; de Nardis, R.; Pappone, G.; Cesarano, M.; Aucelli, P.; Lavecchia, G. Segmentation pattern and structural complexities in seismogenic extensionalsettings: The North Matese Fault System (Central Italy). J. Struct. Geol. 2017, 95, 93-112. [CrossRef]

115. Russo, F.; Terribile, F. Osservazioni geomorfologiche, stratigrafiche e pedologiche sul Quaternario del Bacino di Bojano (Campobasso). Quaternario 1995, 8, 239-254.

116. Guerrieri, L.; Scarascia Mugnozza, G.; Vittori, E. Analisi stratigrafica e geomorfologica della conoide tardo-quaternaria di Campochiaro ed implicazioni per la conca di Boiano in Molise. Quaternario 1999, 12, 237-247.

117. ISTAT-Istituto Nazionale di Statistica. Classificazione dei Comuni in Base alla Densità Turistica. Available online: https: //www.istat.it/it/archivio/247191 (accessed on 5 December 2021). 